Article

\title{
Onion (Allium cepa L.) Yield and Growth Dynamics Response to In-Season Patterns of Nitrogen and Sulfur Uptake
}

\author{
Katarzyna Przygocka-Cyna ${ }^{1, *}$, Przemysław Barłóg ${ }^{1}\left(\mathbb{D}\right.$, Witold Grzebisz ${ }^{1}(\mathbb{D}$ \\ and Tomasz Spiżewski ${ }^{2}$ \\ 1 Department of Agricultural Chemistry and Environmental Biogeochemistry, Poznan University of \\ Life Sciences, Wojska Polskiego 28, 60-637 Poznan, Poland; przemyslaw.barlog@up.poznan.pl (P.B.); \\ witold.grzebisz@up.poznan.pl (W.G.) \\ 2 Department of Vegetables Production, Poznan University of Life Sciences, Wojska Polskiego 71F, \\ 60-625 Poznań, Poland; tomasz.spizewski@up.poznan.pl \\ * Correspondence: katarzyna.przygocka-cyna@up.poznan.pl; Tel.: +48-618-486-285
}

Received: 23 June 2020; Accepted: 4 August 2020; Published: 6 August 2020

\begin{abstract}
The in-season trend of onion biomass and its yield depend on the dynamics of nitrogen (N) and sulfur (S) uptake. This hypothesis was verified based on a three-year $(2009,2010,2011)$ field study (Poznan University of Life Sciences). The experimental factors consisted of N: 0, 60, 120 and S: 0, 30, $60 \mathrm{~kg} \mathrm{ha}^{-1}$. The dynamics of onion total dry weight (TDW), total $\mathrm{N}$ uptake (TNU), and total S uptake (TSU) were determined at 10-day intervals. The in-season course of TDW and TNU was best described by the expolinear and TSU by the quadratic growth model. Sulfur uptake increased in onion at day after emergence (DAE) 40, independent of its rate with respect to SN control, resulting in increased $\mathrm{N}$ by $50 \%$, and consequently higher yield. The maximum absolute $\mathrm{S}$ uptake rate $\left(\mathrm{SC}_{\mathrm{m}}\right)$, a factor defining yield, increased progressively with the $\mathrm{N}$ rate, but only in the absence of $\mathrm{S}$ application. Plants fertilized simultaneously with $\mathrm{S}$ and $\mathrm{N}$ showed a more complicated impact on $\mathrm{SC}_{\mathrm{m}}$. The $\mathrm{N}$ rate of $120 \mathrm{~kg} \mathrm{ha}^{-1}$ resulted in $\mathrm{SC}_{\mathrm{m}}$ reduction, leading to a yield drop. The expolinear model indicated an onion growth disturbance, revealed under unfavorable growth conditions, leading to yield depression.
\end{abstract}

Keywords: bulb yield; elemental sulfur; growth patterns; onion leaves; nitrogen fertilization

\section{Introduction}

Vegetables from the Allium genus, such as onion (A. cepa), garlic (A. sativum), and leek (A. ampeloprasum var. porrum), are among the main sources of bioactive compounds in the human diet all over the world. Onion (Allium cepa L.) is the most widely cultivated species of the genus Allium. Both onion parts-leaves, but especially the bulb-are rich sources of bioactive compounds, mainly polyphenols, among which flavonoids dominate, characterized by elevated antioxidant and antibacterial activities. The qualitative health attributes of onion are widely exploited in human protection against cancer, high blood pressure, and infection [1,2].

On a worldwide scale, onions are among the most commonly consumed vegetables after carrots, cabbages, tomatoes, and cucumbers. Onion has gained in popularity during the last decades of the 20th century. Onion consumption has reached high levels in the United States and Europe [3]. The largest onion producers are China, India, the USA, Pakistan, and Turkey. In Europe, the leading producers are Russia, the Netherlands, Spain, Poland, and Germany [4-6]. The highest yields, at levels of 48-52 $\mathrm{t} \mathrm{ha}{ }^{-1}$, are reached in the United States and the Netherlands, while the world average is much lower at around 
$19 \mathrm{t} \mathrm{ha}^{-1}$. In Poland, onion yields are low, ranging in the last decade around 20-25 t ha ${ }^{-1}$ [4]. In spite of this, onion currently accounts for almost $40 \%$ of domestic exports of unprocessed vegetables [5].

Onion is a vegetable crop with a high requirement for nutrients. The unit nutrient accumulation of a moderately yielding onion is as follows: $\mathrm{N}: 4.2 ; \mathrm{P}: 0.8 ; \mathrm{K}: 3.9$; and Ca: $2.73 \mathrm{~kg} \mathrm{t}^{-1}$ of fresh weight (FW) of total onion biomass at harvest [7]. These values are much higher compared to data for high yielding onion: $\mathrm{N}: 2.2 ; \mathrm{P}: 0.5 ; \mathrm{K}: 2.2 ; \mathrm{Ca}: 0.6 ; \mathrm{Mg}: 0.2 ;$ and S: $0.6 \mathrm{~kg} 1.0 \mathrm{t}^{-1} \mathrm{FW}$ [8]. Applying fertilizers is therefore an important agronomic practice to increase the yields of vegetables including onion, but its response to applied amounts mostly depends on the fertility status of the soil. Continuous work on improving soil fertility conditions for onions creates a basis for the effective use of fertilizer $\mathrm{N}[9,10]$. Applied $\mathrm{N}$ doses fluctuate from about 50 to above $200 \mathrm{~kg} \mathrm{ha}^{-1}$, depending on the region, type of growing onion, and other production practices, like irrigation [11,12]. Too high an $\mathrm{N}$ dose or late application leads to prolonged growth of leaves and delayed bulb maturity. In addition, prolonged leaf growth delays or prevents bulbing, consequently resulting in a yield decline [13].

The role of nutrients in the efficiency of $\mathrm{N}$ fertilizers is frequently limited to phosphorus $(\mathrm{P})$ and potassium $(\mathrm{K})[12,14]$. However, there is growing interest among farmers in the application of $\mathrm{S}$ fertilizers to onion. There are two key reasons for $S$ use in onion cultivation: yield and, even more important, the expected impact of $S$ fertilizers on bulb pungency and the production of bioactive compounds [15,16]. The uptake of $S$ by a high yielding onion can reach as high as $100 \mathrm{~kg} \mathrm{ha}^{-1}$. Therefore, onion is frequently referred to as a sulfur-loving crop. It is for these reasons that $\mathrm{S}$ is the essential fertilizer for proper development, high bulb yield, and high levels of bioactive compounds.

In spite of the above presented facts, onion response to $S$ fertilizer is a matter of controversy [17], based on data from pot experiments showing that increasing $\mathrm{N}$ rates significantly affected biomass, $\mathrm{N}$ and $\mathrm{S}$ uptake, and pungency of onion cultivars $[17,18]$. Some onion covarieties showed a stronger response to $\mathrm{N}$ than to $\mathrm{S}$ supply. However, extremely high rates of $\mathrm{N}$ can reduce $\mathrm{S}$ uptake by onion plants and decrease bulb pungency. In most cases field studies have shown a positive impact of applied $S$ on onion yield. The optimum range of applied $S$ ranges from 30 to $60 \mathrm{~kg} \mathrm{ha}^{-1}$ as recorded in different countries [18-20]. In contrast, no impact of $S$ application to field-grown onion on either yield or bulb pungency was found in [21]. One of the key reasons for the very broad S ranges is the type of applied fertilizer.

The dominant $\mathrm{S}$ carrier is gypsum $[18,22,23]$, and to a much lower degree elemental sulfur $\left(S^{0}\right)[24,25]$. A comparative study on the impact of gypsum and $S^{0}$ on onion yield revealed an advantage of gypsum [20,26]. An analysis of the interactional impact of $\mathrm{N}$ and $\mathrm{S}$ on onion growth, yield, and bioactive compounds highlighted the necessity to optimize the doses of both nutrients [22].

In spite of numerous experiments devoted to the response of onion to $\mathrm{N}$ or $\mathrm{S}$ application and their interactive impact on yield, the in-season trend of dry matter, $\mathrm{N}$, and $\mathrm{S}$ accumulation is not known. This is the main weakness of any study on the yield-forming function of these two nutrients. The key objective of the present study was to define in-season models of dry matter, $\mathrm{N}$, and $\mathrm{S}$ accumulation by onion and the parameters of the functions obtained. The next objective of this study was to define a set of parameters responsible for onion yield.

\section{Materials and Methods}

\subsection{Site Description}

Field tests on onion (Allium cepa L.) growth during the growing season were conducted in 3 consecutive years, 2009, 2010, and 2011, at the Brody Experimental Farm (University of Life Sciences in Poznan; $52^{\circ} 44^{\prime} \mathrm{N}, 16^{\circ} 28^{\prime}$ E). The field experiment was established on soil originating from loamy sand lying on sandy loam, and classified as Albic Luvisol (WRB, 2015). Soil pH was variable, ranging from acid in 2010 to slightly acid in the other two years. The content of $\mathrm{S}^{-\mathrm{SO}_{4}}$ was in the high class in 2009 and 2010, and in the medium class in 2011 [27]. The content of mineral nitrogen $\left(\mathrm{N}_{\min }\right)$ was highly variable between years, from $10 \mathrm{~kg} \mathrm{ha}^{-1}$ in 2010 to over $60 \mathrm{~kg} \mathrm{ha}^{-1}$ in 2011 . Soil fertility level, 
as evaluated by the content of available P, was very high. The content of available K was low in 2009 and very low in the other two years of the study (Table 1).

Table 1. Agrochemical characteristics of soil in research plots.

\begin{tabular}{|c|c|c|c|c|c|}
\hline Years & pH (1M KCl) & $\mathrm{S}-\mathrm{SO}_{4}{ }^{1}\left(\mathrm{mg} \mathrm{kg}^{-1}\right)$ & $\mathrm{N}_{\min }{ }^{2}\left(\mathrm{~kg} \mathrm{ha}^{-1}\right)$ & $\mathrm{P}_{2} \mathrm{O}_{5}{ }^{3}\left(\mathrm{mg} \mathrm{kg}^{-1}\right)$ & $\mathrm{K}_{2} \mathrm{O}^{3}\left(\mathrm{mg} \mathrm{kg}^{-1}\right)$ \\
\hline 2009 & 6.13 & $12.34^{\mathrm{H}}$ & 15.89 & $227^{\mathrm{VH}}$ & $113^{\mathrm{L}}$ \\
\hline 2010 & 5.19 & $17.60^{\mathrm{H}}$ & 9.96 & $252 \mathrm{VH}$ & $84 \mathrm{VL}$ \\
\hline 2011 & 6.30 & $6.90^{\mathrm{M}}$ & 62.3 & $360 \mathrm{VH}$ & $94 \mathrm{VL}$ \\
\hline
\end{tabular}

${ }^{1}$ Nephelometric method of [28]. ${ }^{2} 0.01 \mathrm{CaCl}_{2}$ solution. ${ }^{3}$ Egner-Riehm standard procedure. Content of plant available nutrients: ${ }^{\mathrm{VL}}$ very low, ${ }^{\mathrm{L}}$ low, ${ }^{\mathrm{M}}$ medium, ${ }^{\mathrm{H}}$ high, ${ }^{\mathrm{VH}}$ very high.

The local climate, classified as intermediate between Atlantic and Continental, is seasonally variable (Figure 1). The total amount of precipitation during the onion growing season (April-August) was $267 \mathrm{~mm}$ in 2009, $356 \mathrm{~mm}$ in 2010, and $310 \mathrm{~mm}$ in 2011, whereas the long-term (1961-2009) average is $301 \mathrm{~mm}$. The average temperature during the onion growing season was $14.7^{\circ} \mathrm{C}$ in $2009,16.2^{\circ} \mathrm{C}$ in 2010, and $16.2^{\circ} \mathrm{C}$ in 2011 , whereas the long-term (1961-2009) average is $14.6^{\circ} \mathrm{C}$.

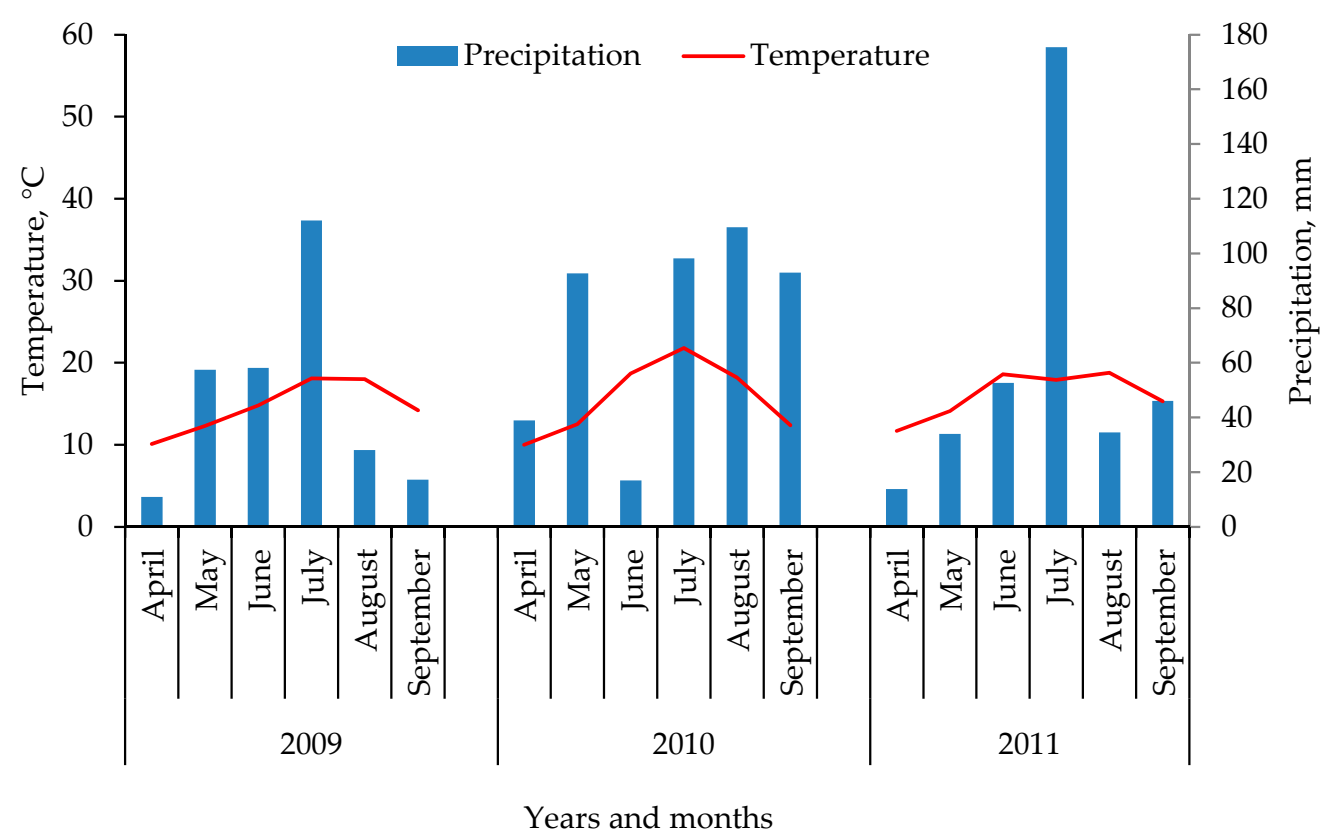

Figure 1. Mean monthly air temperature and precipitation during 2009-2011 growing seasons of onion.

\subsection{Experimental Design}

The field experiment was a randomized complete block design, replicated fourfold, comprising 2 factors:

(1) S rate: 0,30 , and $60 \mathrm{~kg} \mathrm{ha}^{-1}$ in the form of elemental sulfur, $\mathrm{S}^{0}(96 \% \mathrm{~S})$

(2) $\mathrm{N}$ rate: 0,60 , and $120 \mathrm{~kg} \mathrm{ha}^{-1}$ in the form of ammonium nitrate $(34 \% \mathrm{~N})$

$\mathrm{P}$ as a triple superphosphate $\left(\mathrm{Ca}\left(\mathrm{H}_{2} \mathrm{PO}_{4}\right)_{2} \times \mathrm{H}_{2} \mathrm{O}, 46 \% \mathrm{P}_{2} \mathrm{O}_{5}\right)$ was applied at the rate of $23.2 \mathrm{~kg} \mathrm{Pha}{ }^{-1}$, and $\mathrm{K}$ as $\mathrm{KCl}$ at the rate of $83 \mathrm{~kg} \mathrm{~K} \mathrm{ha}^{-1}$. All nutrients, including ammonium nitrate $\left(\mathrm{NH}_{4} \mathrm{NO}_{3}\right)$, were applied 2 weeks before onion sowing. The total area of a single plot was $39.2 \mathrm{~m}^{2}$. The onion variety Supra was sown each year at the beginning of April and managed consistently with the codex of good agricultural practice. The preceding crop was spring barley. The onion was hand harvested at the end of August from an area of $19.2 \mathrm{~m}^{2}$. 


\subsection{Experimental Measurements and Chemical Analysis}

The plant material used for dry weight (DW) determination and measurement of nutrient concentrations was collected from an area of $1.0 \mathrm{~m}^{2}$. Periodic harvesting was conducted at 10-day intervals, starting from the 20th day after emergence (DAE). The sampled material was then divided, depending on the stage of growth, into subsamples of leaves and bulb; they were dried at $60^{\circ} \mathrm{C}$ and ground in a mill. Total dry weight (TDW) of plants is the sum of bulb and leaf DW. The bulb dry weight index (BDWI) is a share of bulb DW in TDW. Nitrogen concentration in plant samples was determined using a standard macro-Kjeldahl procedure. For total $\mathrm{S}$ determination, the turbidometric method was used [26]. All results are expressed based on DW. Nutrient content was calculated by multiplying its concentration and DM of bulbs and leaves.

\subsection{Growth and Nutrient Uptake Dynamics Parameters}

The expolinear model was used to determine the parameters characterizing crop growth dynamics. The model describes 2 phases of plant growth, exponential at first and then linear growth of the crop. The function parameters were determined separately for each year of the study $(n=72)$ and for every $\mathrm{N}$ and $\mathrm{S}$ fertilization treatment $(\mathrm{n}=24)$ using an Equation in [29]:

$$
\mathrm{TDW}=\left(\mathrm{C}_{\mathrm{m}} / \mathrm{R}_{\mathrm{m}}\right) \times \log _{\mathrm{e}}\left[1+\mathrm{e}^{(\mathrm{Rm}(\mathrm{T}-\mathrm{Tb}))}\right]
$$

where TDW is total dry weight of plant per unit ground area $\left(\mathrm{g} \mathrm{m}^{-2}\right) ; \mathrm{C}_{\mathrm{m}}$ is maximum absolute crop growth rate in the linear phase $\left(\mathrm{g} \mathrm{m}^{-2} \mathrm{~d}^{-1}\right) ; \mathrm{R}_{\mathrm{m}}$ is maximum relative growth rate in the exponential phase $\left(\mathrm{g} \mathrm{g}^{-1} \mathrm{~d}^{-1}\right)$; $\mathrm{T}$ is time of plant harvest (days after emergence, $\mathrm{d}$ ); and $\mathrm{T}_{\mathrm{b}}$ is time when the canopy changes from exponential to linear growth $(\mathrm{d})$.

The expolinear model was adjusted using Statistica 13 software to obtain the determination coefficient $\left(R^{2}\right)$ between measured and estimated values using the loss function $(\mathrm{L}=\mathrm{Obs}-\mathrm{Pred})^{2}$. Based on the function parameters obtained, 2 additional indices were calculated: $\mathrm{TDW}_{\mathrm{Tb}}$, predicted total plant dry weight at time $\mathrm{T}_{\mathrm{b}}\left(\mathrm{g} \mathrm{m}^{-2}\right)$, and $\mathrm{R}_{\mathrm{L}}$, relative growth rate in the linear phase $\left(\mathrm{g} \mathrm{g}^{-1} \mathrm{~d}^{-1}\right)$. $\mathrm{R}_{\mathrm{L}}$ was calculated as follows [30]:

$$
\mathrm{R}_{\mathrm{L}}=\log _{\mathrm{e}} \mathrm{TDW}_{2}-\log _{\mathrm{e}} \mathrm{TDW} \mathrm{W}_{1} / \mathrm{T}_{2}-\mathrm{T}_{1}
$$

where $\mathrm{TDW}_{1}$ is predicted total dry weight at time $\mathrm{T}_{1}=80$ days after emergence $\left(\mathrm{g} \mathrm{m}^{-2}\right)$ and $\mathrm{TDW}_{2}$ is total dry weight at time $\mathrm{T}_{2}=90$ days after emergence $\left(\mathrm{g} \mathrm{m}^{-2}\right)$.

A similar procedure was followed for N. In respect to $S$, second-order polynomial functions (quadratic curves) provided the best fit to the data obtained:

$$
\begin{gathered}
\text { TSU }=a+b \mathrm{~T}+c \mathrm{~T}^{2} \\
\log _{\mathrm{e}} \mathrm{TSU}=a+b \mathrm{~T}+c \mathrm{~T}^{2}
\end{gathered}
$$

where TSU is total S uptake $\left(\mathrm{mg} \mathrm{m}^{-2}\right)$; T is time of plant harvest (days after emergence, $\mathrm{d}$ ); and $a, b$, and $c$ are parameters from the quadratic function.

The parameters characterizing the dynamics of $S$ accumulation and absolute and relative $S$ uptake rates were calculated as derivatives of the function [30]. The maximum absolute $S$ uptake rate $\left(\mathrm{SC}_{\mathrm{m}}\right)$ was computed at time $T_{2}=90$ days after emergence $\left(\mathrm{mg} \mathrm{m}^{-2} \mathrm{~d}^{-1}\right)$ and maximum relative $S$ uptake rate at $\mathrm{T}=20$ days after emergence $\left(\mathrm{SR}_{\mathrm{m}}, \mathrm{mg} \mathrm{d}^{-1} \mathrm{~d}^{-1}\right)$. In addition, total $\mathrm{S}$ accumulation at $\mathrm{T}_{2}\left(\mathrm{TSU}_{\mathrm{T} 2}\right.$, $\mathrm{mg} \mathrm{m}^{-2}$ ) was computed using the obtained function parameters.

\subsection{Statistical Analysis}

The effect of individual research factors (year, sulfur, nitrogen) and the interactions between them were assessed by means of three-way ANOVA. Fisher's F-test was used to evaluate factorial effects. 
The significance level of the F-test is indicated by asterisks: ${ }^{*} p<0.05,{ }^{* *} p<0.01$, and ${ }^{* * *} p<0.001$. Means were separated by honestly significant difference (HSD-test) using Tukey's method when the F-test indicated significant factorial effects at least at the level of $p<0.05$. Homogeneous groups are indicated with the same superscript letters. Means not sharing any the same letter are significantly different by the HSD-test at the $5 \%$ level of significance. The relationships between traits were analyzed using Pearson correlation. Statistica 13 software was used for all statistical analyses (StatSoft Inc., Tulsa, OK, USA, 2013).

\section{Results}

\subsection{Yield of Onion Bulbs}

The key factor affecting the yield of onion bulbs is the course of the weather in a particular growing season, i.e., year $\left(F_{2.54}=297.8, p<0.001\right)$. The highest yield was recorded in 2009, followed by 2011, and the lowest in 2010 (Figure 2a). Averaged over experimental years, harvested yield was at the level of $2338 \mathrm{~g} \mathrm{~m}^{-2}$ of bulb FW. The effect of the $\mathrm{S}$ rate on onion yield was independent of year and $\mathrm{N}$ rate. Each year, a linear yield increase up to an $S$ rate of $60 \mathrm{~kg} \mathrm{ha}^{-1}$ was recorded. As a result, $\mathrm{S}$ application significantly increased the mean yield compared to the control $\left(F_{2,54}=10.1, p<0.001\right)$. The relative yield increase averaged over $\mathrm{N}$ rates and years was $8.9 \%$ and $12.9 \%$ for an $\mathrm{S}$ rate of 30 and $60 \mathrm{~kg} \mathrm{ha}^{-1}$ (Figure 2a).
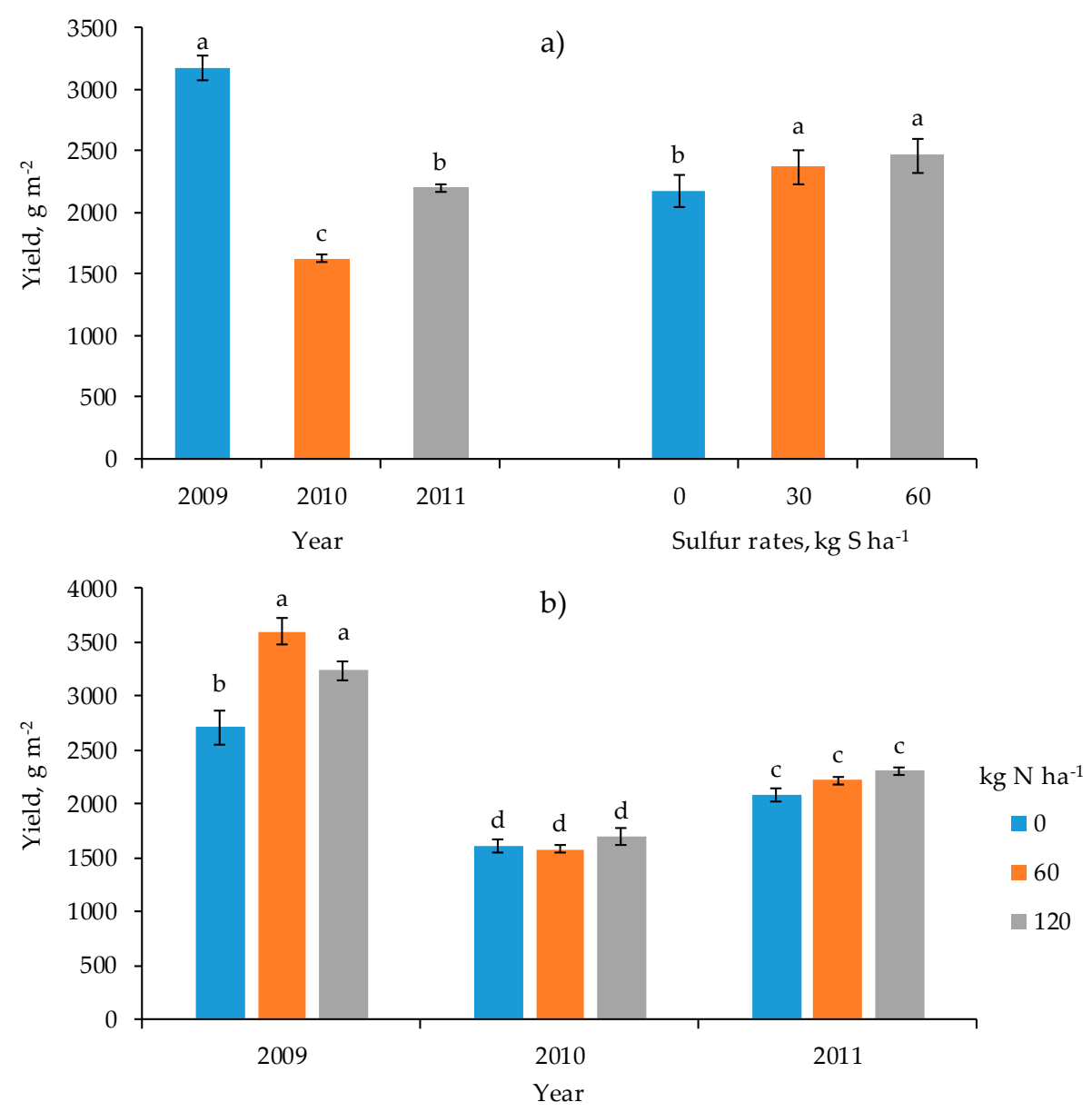

Figure 2. (a) Yield of onion bulb fresh matter (FM) depending on the year and sulfur application; and (b) interaction between year and $\mathrm{N}$ rates. Letters indicate statistically significant differences between treatments at $p<0.05$ (honestly significant difference (HSD) test). Hatched bars represent $2 \times$ SEM ranges. 
In the case of $\mathrm{N}$, its effect was variable in consecutive years of the study $\left(F_{4.54}=9.9, p<0.001\right)$. In 2009, the yield significantly responded to $\mathrm{N}$ rates, reaching the highest value with fertilizer treatment of $60 \mathrm{~kg} \mathrm{ha}^{-1}\left(+32.8 \%\right.$ compared to the $\mathrm{N}$ control). Plants fertilized with an $\mathrm{N}$ rate of $120 \mathrm{~kg} \mathrm{ha}^{-1} \mathrm{had}$ much lower yield ( $+19.6 \%$ with respect to the $\mathrm{N}$ control). In 2010 and 2011, the effect of $\mathrm{N}$ doses was not significant, but a positive trend was observed on plots fertilized with the highest rate of $\mathrm{N}$ (Figure 2b).

\subsection{Dry Matter Accumulation Dynamics}

Weather was the key factor, significantly differentiating the total dry weight (TDW) of onion plants (leaves + bulb) in consecutive samplings during the season (Figure 3). At harvest, the highest TDW of onion was recorded in 2009, and the lowest in 2010. The difference between these two years was double, reaching 122\%, but between 2010 and 2011 was only 50.2\%. Following the 50th DAE, the onion plant began a phase of bulbing and a partition of total onion biomass between leaves (chive) and bulb was recorded. In 2009, the bulb biomass doubled in the period from DAE 70 to 80 . A significant but smaller increase was recorded following the 80th DAE, although the biomass of leaves increased at a much slower rate, but progressively. A slightly different pattern was revealed in 2010 . The progressive bulb increase lasted up to the 80th DAE, and then stopped. At the same time, leaf biomass did not show any increase. A completely different pattern of onion growth was observed in 2011. The bulb biomass increased step-by-step up to harvest, but growth of leaves stopped on the 70th DAE.

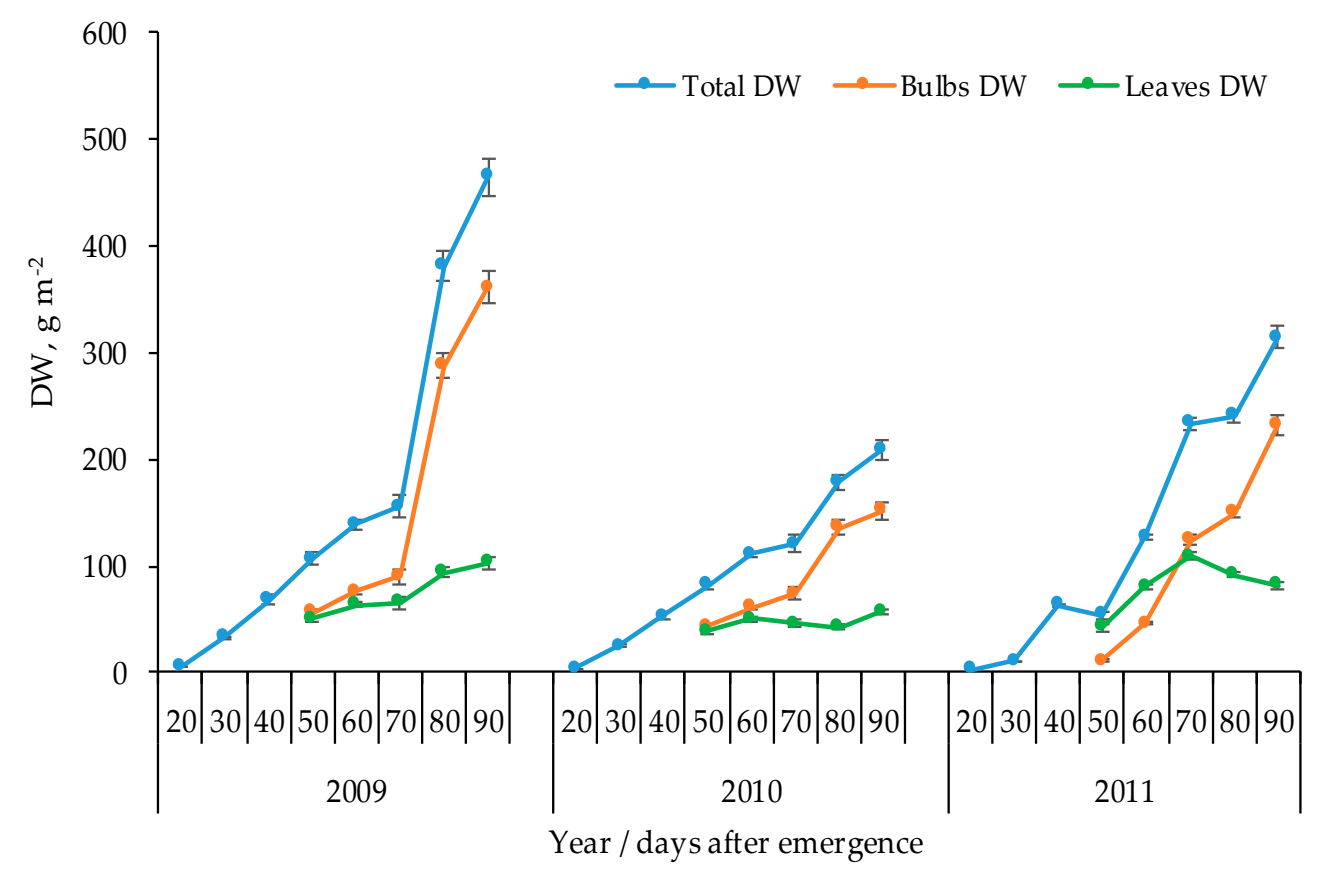

Figure 3. Total dry weight (TDW) and its partitioning among organs of onion plants during the growing season. Hatched bars represent $2 \pm$ SEM ranges.

As shown in Table 2, the bulb dry weight index (BDWI) showed a linear trend, reaching values ranging from $72 \%$ in 2010 to $77 \%$ at harvest in 2009 . At the onset of bulbing (50 DAE), the lowest BDWI index of $23 \%$ was recorded in 2011, whereas in other years it was 2.5-fold higher. The key reason for the low value in this particular year was a high content of soil mineral $\mathrm{N}$ at sowing (Table 1). This pattern of onion growth fully corroborates the opinion in [13] that a high N supply during the early stages of development extends the phase of leaf growth. Nevertheless, the rate of bulb growth in later stages was sufficiently high to reach a BDWI of $74 \%$ at harvest. 
Table 2. Onion bulb dry weight index (BDWI) in relation to year and day after emergence (DAE).

\begin{tabular}{cccccc}
\hline \multirow{2}{*}{ Year } & \multicolumn{5}{c}{ DAE } \\
\cline { 2 - 6 } & $\mathbf{5 0}$ & $\mathbf{6 0}$ & $\mathbf{7 0}$ & $\mathbf{8 0}$ & $\mathbf{9 0}$ \\
\hline 2009 & $0.53^{\mathrm{a}}$ & $0.55^{\mathrm{a}}$ & $0.58^{\mathrm{b}}$ & $0.75^{\mathrm{a}}$ & $0.77^{\mathrm{a}}$ \\
2010 & $0.52^{\mathrm{a}}$ & $0.55^{\mathrm{a}}$ & $0.62^{\mathrm{a}}$ & $0.75^{\mathrm{a}}$ & $0.72^{\mathrm{b}}$ \\
2011 & $0.23^{\mathrm{b}}$ & $0.37^{\mathrm{b}}$ & $0.53^{\mathrm{b}}$ & $0.62^{\mathrm{b}}$ & $0.74^{\mathrm{b}}$ \\
$F$-test & $266.3^{* * *}$ & $78.5^{* * *}$ & $11.5^{* * *}$ & $89.0^{* * *}$ & $12.1^{* * *}$ \\
\hline
\end{tabular}

$*, * *, \overline{* * *} F$-test significant at $p<0.05,0.01,0.001$, respectively. Letters indicate statistically significant differences between treatments at $p<0.05$ (HSD test).

The in-season trend of TDW compared to onion yield was, in general, significantly affected by the weather. On consecutive sampling dates, however, onion biomass was differentiated by the interaction of applied doses of $\mathrm{N}$ and $\mathrm{S}$. The degree of impact of a particular factor on onion TDW was DAE-specific. Experimental factors did not affect TDW on the 20th and 60th DAE (Table 3).

Table 3. Total dry weight (TDW) and onion bulb dry weight index (BDWI) in relation to interaction between $\mathrm{N}$ and $\mathrm{S}$ rates and day after emergence (DAE).

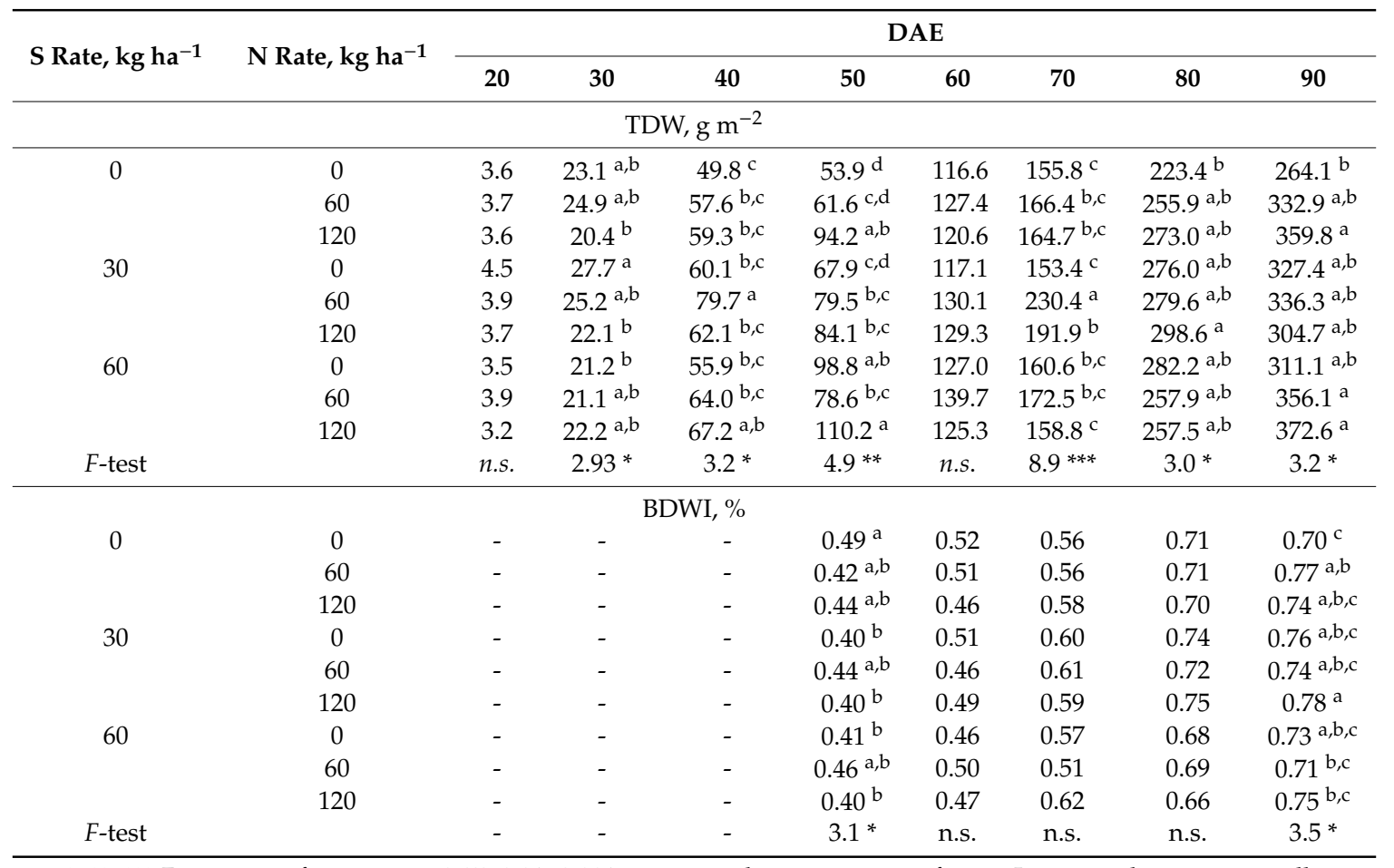

$*{ }^{* * *}, * * F$-ratio significant at $p<0.05,0.01,0.001$, respectively. $n . s .$, not significant. Letters indicate statistically significant differences between treatments at $p<0.05$ (HSD test).

In general, beginning on the 40th DAE, the lowest onion TDW was recorded each year on the absolute control plot $\left(\mathrm{S}_{0}+\mathrm{N}_{0}\right.$ treatment, acronym $\left.\mathrm{AC}\right)$.

On the 30th DAE, the highest biomass was recorded at the $S_{30}+N_{0}$ plot. In the next 10 days, the highest biomass was recorded at two plots, $\mathrm{S}_{30}+\mathrm{N}_{60}$ and $\mathrm{S}_{60}+\mathrm{N}_{120}$. On the 70th DAE, the highest TDW was again found at the $S_{30}+N_{60}$ plot, and 20 days later at the $S_{60}+N_{120}$ plot. A significant difference with respect to the absolute control (AC) at DAE 90 was also recorded on the $\mathrm{S}_{0}+\mathrm{N}_{120}$ and $\mathrm{S}_{60}+\mathrm{N}_{60}$ treatments.

The significant impact of fertilization on BDWI values was recorded on two sampling dates, on the 50th and 90th DAE (Table 3). The highest BDWI value of $49 \%$ at 50 DAE was found at the AC plot. Significantly lower indices were recorded on plots fertilized with $S$. This phenomenon can be explained by the higher supply of $\mathrm{N}$ to the growing plants, subsequently resulting in delayed onion bulbing [13]. 
The parameters of the expolinear model characterizing the dynamics of onion TDW during the growing season are shown in Table 4. In 2009, plants showed a higher growth rate, as expressed by $\mathrm{C}_{\mathrm{m}}$, during the linear phase of growth. The value of this parameter was ninefold and fivefold higher as recorded in 2010 and 2011, respectively. The main reason for these differences was the delay in the day of growth pattern change from exponential to linear $\left(\mathrm{T}_{\mathrm{b}}\right)$.

Table 4. Dynamics of total dry weight of Allium cepa depending on year and fertilization treatment: parameters of expolinear model.

\begin{tabular}{|c|c|c|c|c|c|c|c|}
\hline Factors & & $\mathrm{C}_{\mathrm{m}} \mathrm{d} \mathrm{m}^{-1}$ & $\underset{d^{-1}}{R_{m} g^{-1}}$ & $\mathrm{R}_{\mathrm{L}} \mathrm{g} \mathrm{g}^{-1}$ & $\begin{array}{l}T_{b} \\
d^{-1}\end{array}$ & $\begin{array}{c}\mathrm{TDW}_{\mathrm{Tb}} \mathrm{g} \\
\mathrm{m}^{-2}\end{array}$ & $\mathbf{R}^{2}$ \\
\hline \multicolumn{8}{|l|}{ Year } \\
\hline 2009 & & 30.7 & 0.052 & 0.038 & 85.9 & 411.9 & 91.4 \\
\hline 2010 & & 3.4 & 0.117 & 0.018 & 28.1 & 20.0 & 89.5 \\
\hline 2011 & & 6.1 & 0.123 & 0.021 & 38.4 & 34.6 & 93.4 \\
\hline $\begin{array}{l}\text { S Rate kg S } \\
\text { ha }^{-1}\end{array}$ & $\begin{array}{c}\text { N Rate kg N } \\
\text { ha }^{-1}\end{array}$ & & & & & & \\
\hline \multirow[t]{3}{*}{0} & 0 & 5.7 & 0.083 & 0.023 & 43.4 & 47.9 & 74.9 \\
\hline & 60 & 10.2 & 0.062 & 0.029 & 59.4 & 114.1 & 73.5 \\
\hline & 120 & 15.0 & 0.052 & 0.032 & 72.4 & 199.7 & 79.0 \\
\hline \multirow[t]{3}{*}{30} & 0 & 10.9 & 0.059 & 0.030 & 62.0 & 127.1 & 88.0 \\
\hline & 60 & 14.3 & 0.056 & 0.031 & 65.9 & 177.9 & 86.3 \\
\hline & 120 & 10.1 & 0.068 & 0.027 & 54.2 & 102.6 & 87.2 \\
\hline \multirow[t]{3}{*}{60} & 0 & 7.1 & 0.074 & 0.024 & 45.7 & 67.3 & 87.3 \\
\hline & 60 & 12.4 & 0.054 & 0.030 & 66.1 & 159.2 & 77.1 \\
\hline & 120 & 51.9 & 0.042 & 0.037 & 114.6 & 852.0 & 73.8 \\
\hline
\end{tabular}

$\mathrm{C}_{\mathrm{m}}$, maximum absolute crop growth rate in linear phase; $\mathrm{R}_{\mathrm{m}}$, maximum relative growth rate in exponential phase; $R_{L}$, relative growth rate in linear phase; $T_{b}$, time when canopy changes from exponential to linear growth; TDW $\mathrm{Tb}_{\mathrm{b}}$, predicted total plant dry matter at $\mathrm{T}_{\mathrm{b}}$.

In 2009, this particular day occurred on the 86th DAE, whereas in 2010 and 2011, it was on the 29 th and 39th DAE, respectively. However, the predicted onion biomass $\left(\mathrm{TDW}_{\mathrm{Tb}}\right)$ at this $\mathrm{T}_{\mathrm{b}}$ was several-fold higher in 2009 compared to other years, clearly corroborating the close relationship with $C_{m}\left(r=0.99^{* * *}\right)$. The relative rate of DW growth during the linear phase $\left(R_{L}\right)$ displayed the same trend as the above-described parameters. A reverse trend was shown by $R_{m}$, a parameter describing the relative rate of onion growth during the exponential phase of development. This parameter was negatively correlated with $\mathrm{R}_{\mathrm{L}}, \mathrm{T}_{\mathrm{b}}, \mathrm{TDW}_{\mathrm{Tb}}$, and finally onion yield (Table S1).

The interactional effect of $\mathrm{S}_{0}$ and $\mathrm{S}_{60}$ and increasing $\mathrm{N}$ rates significantly and positively affected four of five parameters of the developed model: $C_{m}, R_{L}, T_{b}$, and $T D W_{T b}$. The opposite relationship was recorded for $R_{m}$. On the $S_{60}$ mai plot, the highest $C_{m}$ and $R_{L}$ values were recorded for plants fertilized with an $\mathrm{N}$ rate of $60 \mathrm{~kg} \mathrm{ha}^{-1}$, consequently resulting in the highest $\mathrm{TDW}_{\mathrm{Tb}}$. Plants fertilized with an $\mathrm{N}$ rate of $120 \mathrm{~kg} \mathrm{ha}^{-1}$, with the exception of $\mathrm{R}_{\mathrm{m}}$, had much lower values of all parameters of the model. Among the studied treatments, the highest $C_{m}$ was recorded for plants grown on the $\mathrm{S}_{60}+\mathrm{N}_{120}$ plot. Its value ranged from 3.5 to 9-fold higher compared to the values obtained on the $\mathrm{S}_{0}+\mathrm{N}_{0}$ and $\mathrm{S}_{0}+\mathrm{N}_{120}$ plots, respectively. It is necessary to stress that the predicted $\mathrm{TDW} \mathrm{Tb}_{\mathrm{Tb}}$, in spite of being the highest, had only a theoretical value. It was obtained on the 115th DAE, whereas the onions had been harvested 25 days earlier (DAE 90).

\subsection{Nitrogen Uptake Dynamics}

The course of the weather during the study was the key factor affecting total $\mathrm{N}$ uptake (TNU) during consecutive stages of onion growth (Table 5). In general, the highest TNU, except on the 70th DAE, was observed in 2009. The greatest differences between years were found at the beginning of onion growth. A significantly lower N uptake was recorded in 2011 in comparison to 2009 and 2010. The same relationships were again revealed on the 50th DAE. At harvest, the TNU course was in accordance with onion yield (Table 2). 
Table 5. Total $\mathrm{N}$ uptake (TNU) and onion bulb $\mathrm{N}$ index (BNI) in relation to year and day after emergence (DAE).

\begin{tabular}{ccccccccc}
\hline \multirow{2}{*}{ Year } & \multicolumn{7}{c}{ DAE } \\
\cline { 2 - 9 } & $\mathbf{2 0}$ & $\mathbf{3 0}$ & $\mathbf{4 0}$ & $\mathbf{5 0}$ & $\mathbf{6 0}$ & $\mathbf{7 0}$ & $\mathbf{8 0}$ & $\mathbf{9 0}$ \\
\hline \multicolumn{7}{c}{$\mathrm{TNU}, \mathrm{g} \mathrm{m}^{-2}$} \\
\hline 2009 & $0.15^{\mathrm{a}}$ & $0.88^{\mathrm{a}}$ & $2.21^{\mathrm{a}}$ & $3.67^{\mathrm{a}}$ & $4.29^{\mathrm{a}}$ & $4.31^{\mathrm{b}}$ & $9.48^{\mathrm{a}}$ & $10.07^{\mathrm{a}}$ \\
2010 & $0.13^{\mathrm{b}}$ & $0.93^{\mathrm{a}}$ & $1.92^{\mathrm{b}}$ & $2.80^{\mathrm{b}}$ & $3.27^{\mathrm{b}}$ & $3.04^{\mathrm{c}}$ & $4.50^{\mathrm{c}}$ & $5.37^{\mathrm{c}}$ \\
2011 & $0.08^{\mathrm{c}}$ & $0.45^{\mathrm{b}}$ & $2.01^{\mathrm{ab}}$ & $1.02^{\mathrm{c}}$ & $2.61^{\mathrm{c}}$ & $5.29^{\mathrm{a}}$ & $5.56^{\mathrm{b}}$ & $7.39^{\mathrm{b}}$ \\
$F$-test & $67.4^{* * *}$ & $145.9^{* * *}$ & $4.6^{*}$ & $192.6^{* * *}$ & $98.4^{* * *}$ & $82.0^{* * *}$ & $128.5^{* * *}$ & $65.4^{* * *}$ \\
\hline & & & - & $\mathrm{BNI} \%$ & & & & \\
\hline 2009 & - & - & - & 0.41 & $0.48^{\mathrm{b}}$ & $0.53^{\mathrm{b}}$ & $0.69^{\mathrm{b}}$ & $0.66^{\mathrm{b}}$ \\
2010 & - & - & - & 0.41 & $0.48^{\mathrm{b}}$ & $0.53^{\mathrm{b}}$ & $0.70^{\mathrm{b}}$ & $0.64^{\mathrm{b}}$ \\
2011 & - & - & - & 0.38 & $0.57^{\mathrm{a}}$ & $0.75^{\mathrm{a}}$ & $0.77^{\mathrm{a}}$ & $0.85^{\mathrm{a}}$ \\
$F$-test & - & - & - & n.s. & $11.1^{* * *}$ & $78.9^{* * *}$ & $23.1^{* * *}$ & $140.7^{* * *}$ \\
\hline
\end{tabular}

$* \overline{* * * * * *} F$-test significant at $p<0.05,0.01,0.001$, respectively. $n . s .$, not significant. Letters indicate statistically significant differences between treatments at $p<0.05$ (HSD test).

The bulb N index (BNI) increased in a linear mode from about $40 \%$ at the onset of bulbing to about $70 \%$ at the 80th DAE in 2009 and 2010, when it reached its maximum. A slight drop was recorded between the 80th and 90th DAE. In 2011, this index showed a very steep increase from $40 \%$ on the 50th DAE to $85 \%$ on the 90 th DAE (Table 5).

During the growing season, except for the 60th DAE, both TNU and BNI significantly depended on the $\mathrm{N} \times \mathrm{S}$ interaction (Table 6). Sulfur application was a factor that considerably increased $\mathrm{N}$ uptake compared to the absolute control (AC) plot. The differences between experimental treatments depended on the sampling date. At harvest, a significantly higher TNU compared to the AC plot was recorded for the $\mathrm{S}_{30}+\mathrm{N}_{60}, \mathrm{~S}_{60}+\mathrm{N}_{60}$ and $\mathrm{S}_{60}+\mathrm{N}_{120}$ treatments.

Table 6. Total $\mathrm{N}$ uptake (TNU) and onion bulb $\mathrm{N}$ index (BNI) in relation to interaction between $\mathrm{N}$ and $\mathrm{S}$ rates and day after emergence (DAE).

\begin{tabular}{|c|c|c|c|c|c|c|c|c|c|}
\hline \multirow{2}{*}{$\begin{array}{l}\text { S Rate, } \\
\text { kg ha }^{-1}\end{array}$} & \multirow{2}{*}{$\begin{array}{l}\text { N Rate, } \\
\mathrm{kg} \mathrm{ha}^{-1}\end{array}$} & \multicolumn{8}{|c|}{ DAE } \\
\hline & & 20 & 30 & 40 & 50 & 60 & 70 & 80 & 90 \\
\hline \multicolumn{10}{|c|}{ TNU, $\mathrm{g} \mathrm{m}^{-2}$} \\
\hline \multirow[t]{3}{*}{0} & 0 & $0.09^{c}$ & $0.71^{a, b}$ & $1.28^{\mathrm{d}}$ & $1.38^{\mathrm{e}}$ & 2.65 & $3.22^{d}$ & $5.23^{c}$ & $5.22^{b}$ \\
\hline & 60 & $0.12^{b, c}$ & $0.77^{a, b}$ & $1.62^{c, d}$ & $1.90^{\mathrm{d}, \mathrm{e}}$ & 3.31 & $4.07^{b, c, d}$ & $5.31^{b, c}$ & $7.23^{a, b}$ \\
\hline & 120 & $0.12^{b, c}$ & $0.61^{\mathrm{b}}$ & $1.90^{b, c}$ & $3.03^{a, b}$ & 3.34 & $4.14^{\mathrm{b}, \mathrm{c}, \mathrm{d}}$ & $6.52^{a, b, c}$ & $7.59^{a, b}$ \\
\hline \multirow[t]{3}{*}{30} & 0 & $0.13^{b, c}$ & $0.71^{\mathrm{a}, \mathrm{b}}$ & $1.97^{b, c}$ & $1.95^{\mathrm{c}, \mathrm{d}, \mathrm{e}}$ & 2.99 & $3.70^{c, d}$ & $6.03^{b, c}$ & $7.35^{\mathrm{a}, \mathrm{b}}$ \\
\hline & 60 & $0.13^{b, c}$ & $0.81^{\mathrm{a}}$ & $2.73^{\mathrm{a}}$ & $2.49^{b, c, d}$ & 3.83 & $6.08^{a}$ & $6.82^{\mathrm{a}, \mathrm{b}}$ & $9.09^{a}$ \\
\hline & 120 & $0.14^{\mathrm{a}, \mathrm{b}}$ & $0.83^{\mathrm{a}}$ & $2.16^{b, c}$ & $2.51^{b, c, d}$ & 4.00 & $4.93^{b}$ & $8.13^{a}$ & $7.52^{a, b}$ \\
\hline \multirow[t]{3}{*}{60} & 0 & $0.08^{c}$ & $0.70^{a, b}$ & $1.78^{\mathrm{c}, \mathrm{d}}$ & $2.71^{b, c}$ & 2.98 & $3.93^{\mathrm{d}}$ & $7.13^{a, b}$ & $7.07^{a, b}$ \\
\hline & 60 & $0.15^{\mathrm{a}}$ & $0.80^{\mathrm{a}}$ & $2.44^{\mathrm{a}, \mathrm{b}}$ & $2.73^{b}$ & 3.97 & $4.47^{b, c}$ & $6.36^{\mathrm{a}, \mathrm{b}, \mathrm{c}}$ & $8.23^{\mathrm{a}}$ \\
\hline & 120 & $0.14^{\mathrm{a}, \mathrm{b}}$ & $0.82^{\mathrm{a}}$ & $2.53^{a, b}$ & $3.79^{\mathrm{a}}$ & 3.43 & $3.40^{\mathrm{d}}$ & $7.08^{a, b}$ & $9.18^{\mathrm{a}}$ \\
\hline$F$-test & & $5.8^{* * *}$ & $3.1 *$ & $4.0^{* *}$ & $4.5^{* *}$ & n.s. & $8.3^{* * *}$ & $3.2 *$ & $3.1^{*}$ \\
\hline \multicolumn{10}{|c|}{ BNI, $\%$} \\
\hline \multirow[t]{3}{*}{0} & 0 & - & - & - & $0.46^{\mathrm{a}}$ & 0.54 & 0.54 & $0.74^{\mathrm{a}, \mathrm{b}}$ & $0.64^{b}$ \\
\hline & 60 & - & - & - & $0.40^{\mathrm{a}, \mathrm{b}}$ & 0.55 & 0.59 & $0.69^{b}$ & $0.74^{\mathrm{a}, \mathrm{b}}$ \\
\hline & 120 & - & - & - & $0.41^{\mathrm{a}, \mathrm{b}}$ & 0.45 & 0.59 & $0.69^{b}$ & $0.69^{a, b}$ \\
\hline \multirow[t]{3}{*}{30} & 0 & - & - & - & $0.37^{b}$ & 0.56 & 0.60 & $0.73^{\mathrm{a}, \mathrm{b}}$ & $0.75^{\mathrm{a}, \mathrm{b}}$ \\
\hline & 60 & - & - & - & $0.42^{\mathrm{a}, \mathrm{b}}$ & 0.47 & 0.65 & $0.74^{\mathrm{a}, \mathrm{b}}$ & $0.73^{a, b}$ \\
\hline & 120 & - & - & - & $0.36^{\mathrm{b}}$ & 0.52 & 0.65 & $0.79^{a}$ & $0.77^{\mathrm{a}}$ \\
\hline \multirow[t]{3}{*}{60} & 0 & - & - & - & $0.37^{b}$ & 0.46 & 0.59 & $0.73^{\mathrm{a}, \mathrm{b}}$ & $0.71^{a, b}$ \\
\hline & 60 & - & - & - & $0.45^{\mathrm{a}, \mathrm{b}}$ & 0.53 & 0.56 & $0.72^{\mathrm{a}, \mathrm{b}}$ & $0.67^{a, b}$ \\
\hline & 120 & - & - & - & $0.36^{\mathrm{b}}$ & 0.51 & 0.66 & $0.69^{b}$ & $0.74^{\mathrm{a}, \mathrm{b}}$ \\
\hline$F$-test & & - & - & - & $3.7^{*}$ & n.s. & n.s. & $4.0^{* *}$ & $5.5^{* * *}$ \\
\hline
\end{tabular}

${ }^{*}, * *, * * F$-test significant at $p<0.05,0.01,0.001$, respectively. n.s., not significant. Letters indicate statistically significant differences between treatments at $p<0.05$ (HSD test). 
The effect of fertilization on BNI values was also DAE dependent (Table 6). The highest value of this index was recorded on the 50th DAE on the AC plot, and the lowest on plots fertilized with $S$ alone and plots with the highest $\mathrm{N}$ dose $\left(\mathrm{S}_{30}+\mathrm{N}_{120}\right.$ and $\left.\mathrm{S}_{60}+\mathrm{N}_{120}\right)$. At harvest, the highest BNI was found for the $S_{30}+N_{120}$ plot. A significant drop in the index value in the period extending from the 80th and 90th DAE was recorded for the AC plot.

As with TDS, the highest dynamics of $\mathrm{N}$ uptake $\left(\mathrm{NC}_{\mathrm{m}}\right)$ were recorded in 2009 (Table 7). This index was 3.25-fold and 1.63-fold higher compared to 2010 and 2011, respectively. The same trend was observed for $\mathrm{N}_{\mathrm{Tb}}$, i.e., the day when the $\mathrm{N}$ uptake trend changed from exponential to linear and predicted $\mathrm{N}$ uptake $\left(\mathrm{TNU}_{\mathrm{Tb}}\right)$. The differences in $\mathrm{TNU}_{\mathrm{Tb}}$ were extremely pronounced, reaching $3.03 \mathrm{~g} \mathrm{~m}^{-2}$ in 2009 , but only $0.11 \mathrm{~g} \mathrm{~m}^{-2}$ in 2010 . All of these parameters were significantly correlated with each other. In addition, they were positively but not significantly correlated with yield (Table S1). It is necessary to stress that $\mathrm{NC}_{\mathrm{m}}$ and $\mathrm{TNU}_{\mathrm{Tb}}$ were considerably correlated with $\mathrm{C}_{\mathrm{m}}\left(\mathrm{r}=0.95^{* * *}\right)$. A completely reverse annual trend was observed for $\mathrm{NR}_{\mathrm{m}}$, a parameter that describes the maximum rate of $\mathrm{N}$ uptake during the exponential phase of onion growth. The highest value of this parameter was recorded in 2010, i.e., the year with the lowest yield. It was significantly but negatively correlated with parameters of the linear phase of the developed model, but its impact on onion yield was negligible.

Table 7. Dynamics of total N uptake by onion depending on year and fertilization treatment: expolinear model parameters.

\begin{tabular}{|c|c|c|c|c|c|c|c|}
\hline Factors & & $\begin{array}{l}\mathrm{NC}_{\mathrm{m}} \mathrm{g} \\
\mathrm{m}^{-2} \mathrm{~d}^{-1}\end{array}$ & $\underset{d^{-1}}{N R_{m}} g^{-1}$ & $\begin{array}{c}\mathrm{NR}_{\mathrm{L}} \mathrm{g} \mathrm{g}^{-1} \\
\mathrm{~d}^{-1}\end{array}$ & $\begin{array}{l}\mathrm{NT}_{\mathrm{b}} \\
\mathrm{d}^{-1}\end{array}$ & $\begin{array}{c}\mathrm{TNU}_{\mathrm{Tb}} \mathrm{g} \\
\mathrm{m}^{-2}\end{array}$ & $\mathbf{R}^{2}$ \\
\hline \multicolumn{8}{|l|}{ Year } \\
\hline 2009 & & 0.26 & 0.060 & 0.025 & 51.6 & 3.03 & 82.5 \\
\hline 2010 & & 0.08 & 0.478 & 0.021 & 20.5 & 0.11 & 85.3 \\
\hline 2011 & & 0.16 & 0.082 & 0.023 & 43.5 & 1.34 & 87.8 \\
\hline $\begin{array}{c}\text { S Rate kg S } \\
\text { ha }^{-1}\end{array}$ & $\begin{array}{c}\text { N Rate kg N } \\
\mathrm{ha}^{-1}\end{array}$ & & & & & & \\
\hline \multirow[t]{3}{*}{0} & 0 & 0.10 & 0.079 & 0.020 & 36.9 & 0.91 & 76.9 \\
\hline & 60 & 0.15 & 0.071 & 0.022 & 43.2 & 1.46 & 80.9 \\
\hline & 120 & 0.14 & 0.077 & 0.020 & 36.2 & 1.25 & 78.9 \\
\hline \multirow[t]{3}{*}{30} & 0 & 0.13 & 0.064 & 0.021 & 40.8 & 1.45 & 90.2 \\
\hline & 60 & 0.17 & 0.069 & 0.020 & 38.5 & 1.71 & 68.4 \\
\hline & 120 & 0.13 & 0.112 & 0.018 & 28.9 & 0.83 & 71.6 \\
\hline \multirow[t]{3}{*}{60} & 0 & 0.15 & 0.071 & 0.021 & 39.4 & 1.43 & 80.1 \\
\hline & 60 & 0.16 & 0.058 & 0.021 & 42.0 & 1.96 & 72.0 \\
\hline & 120 & 0.29 & 0.050 & 0.027 & 63.2 & 4.06 & 72.2 \\
\hline
\end{tabular}

$\mathrm{NC}_{\mathrm{m}}$, maximum absolute $\mathrm{N}$ accumulation rate in linear phase; $\mathrm{NR}_{\mathrm{m}}$, maximum relative $\mathrm{N}$ accumulation rate in exponential phase; $\mathrm{NR}_{\mathrm{L}}$, relative $\mathrm{N}$ accumulation rate in linear phase; $\mathrm{NT}_{\mathrm{b}}$, time when $\mathrm{N}$ accumulation changes from exponential to linear growth; $\mathrm{TNU}_{\mathrm{Tb}}$, predicted total $\mathrm{N}$ accumulation at $\mathrm{T}_{\mathrm{b}}$.

\subsection{Sulfur Uptake Dynamics}

Total sulfur uptake (TSU) by onion in consecutive stages of plant growth was significantly affected by the year. The observed variability was, however, DAE specific (Figure 4). As a rule, TSU, with the exception of the 70th DAE, was the highest in 2009. The lowest values, except for the 30th DAE, were recorded in 2010. The maximal differences between years, depending on DAE, ranged from $38.8 \%$ (DAE 70) to 368\% (DAE 90). The differences in TSU observed at harvest were in accordance with the differences in bulb yield. Moreover, the observed patterns of TSU were very similar to those described for TDW (Figure 3). A key difference refers to trends in S accumulation in leaves. Its decrease was recorded on the 60th DAE in 2009, and on the 70th DAE in 2010. In spite of this, S accumulation showed a tremendous increase following the 70th DAE in 2009. In 2010, only a slight increase in $S$ in a bulb was observed, which progressed up to the 80th DAE and then decreased. A significant decrease of $S$ in leaves followed the 70th DAE. A completely different pattern was observed in 2011, because up 
to the 70th DAE, the amount of $S$ in the leaves was higher than in the bulb. During the next stages, it suddenly decreased, subsequently resulting in a progressive increase in bulb S.

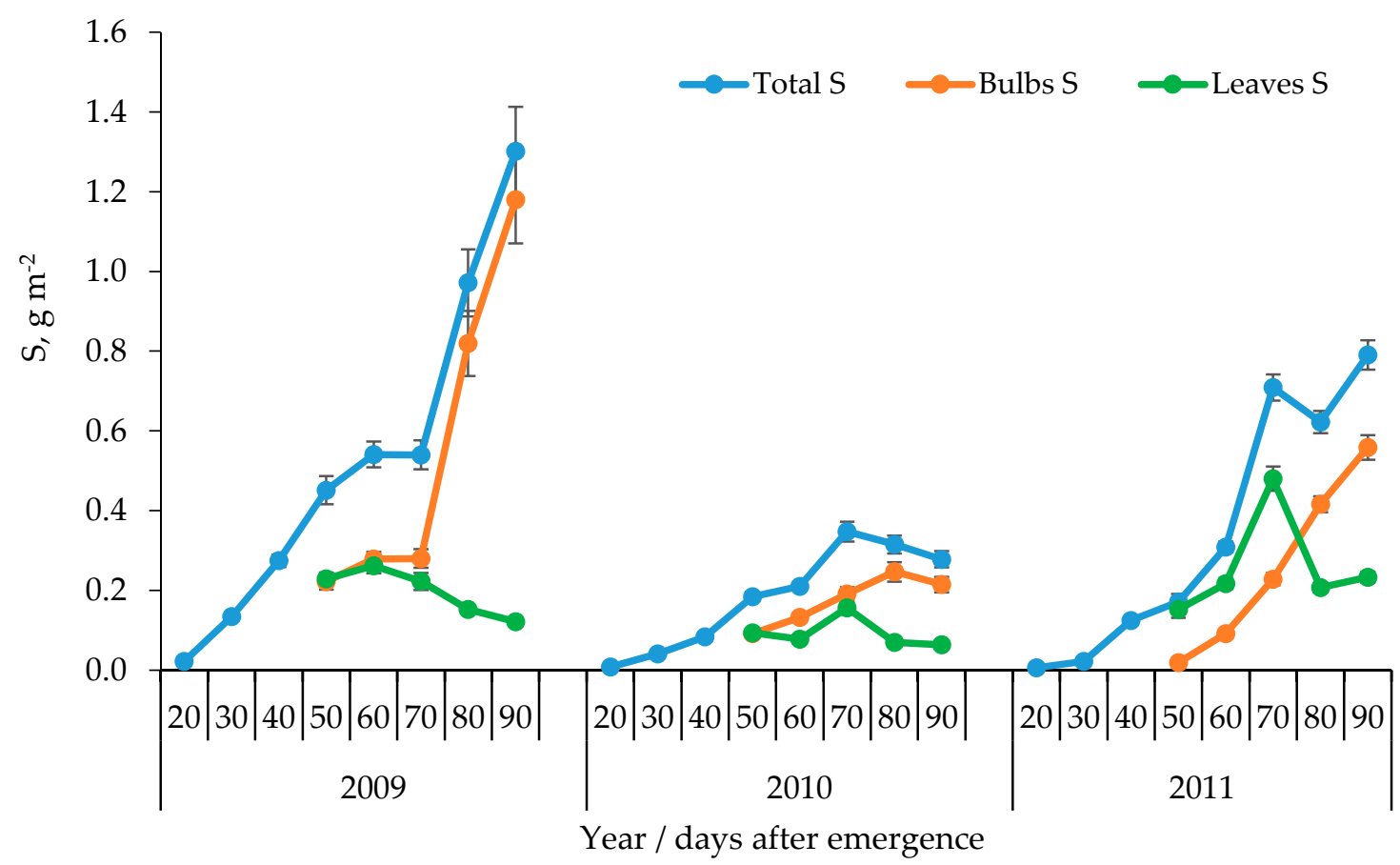

Figure 4. Total sulfur uptake (TSU) and its partitioning among organs of onion plants during the growing season. Hatched bars represent $2 \times$ SEM ranges.

The bulb S index (BSI), which describes the percentage of TSU in onion bulbs, was the lowest at the onset of onion bulbing (DAE 50), increasing progressively in accordance with crop development (Table 8 ). The greatest differences between years were observed in the early stages of onion bulb growth. The slowest increase was observed in 2011, which was significantly lower, especially when compared with 2009. In that year, $89 \%$ of the $S$ taken up by onion finished in the bulb.

Table 8. Onion bulb S index (BSI) in relation to year and day after emergence (DAE).

\begin{tabular}{cccccc}
\hline \multirow{2}{*}{ Year } & \multicolumn{5}{c}{ DAE } \\
\cline { 2 - 6 } & $\mathbf{5 0}$ & $\mathbf{6 0}$ & $\mathbf{7 0}$ & $\mathbf{8 0}$ & $\mathbf{9 0}$ \\
\hline 2009 & $0.48^{\mathrm{a}}$ & $0.52^{\mathrm{b}}$ & $0.54^{\mathrm{a}}$ & $0.81^{\mathrm{a}}$ & $0.89^{\mathrm{a}}$ \\
2010 & $0.49^{\mathrm{a}}$ & $0.61^{\mathrm{a}}$ & $0.55^{\mathrm{a}}$ & $0.75^{\mathrm{b}}$ & $0.75^{\mathrm{a}}$ \\
2011 & $0.15^{\mathrm{b}}$ & $0.31^{\mathrm{c}}$ & $0.33^{\mathrm{b}}$ & $0.67^{\mathrm{c}}$ & $0.70^{\mathrm{a}}$ \\
F-test & $273.4^{* * *}$ & $111.4^{* * *}$ & $48.3^{* * *}$ & $30.7^{* * *}$ & $77.2^{* * *}$ \\
\hline
\end{tabular}

$* * * * * * * F$-test significant at $p<0.05,0.01,0.001$, respectively. Letters indicate statistically significant differences between treatments at $p<0.05$ (HSD test).

Values of TSU were significantly modified by the interaction of $\mathrm{N}$ and $\mathrm{S}$ (Table 9). However, a significant impact of fertilization treatment was recorded in the $\mathrm{S}_{60}+\mathrm{N}_{60}$ treatment on the 60th DAE. At harvest, the highest TSU values, significantly higher compared to AC, were recorded for the same set of treatments as on the 60th DAE and for the $\mathrm{S}_{60}+\mathrm{N}_{120}$ treatment. A significant impact of fertilization on the BSI was only observed on the 60th DAE. Its lowest value was recorded on the $S_{30}+\mathrm{N}_{60}$ plot, and the highest on the $S_{30}+N_{0}$ plot. The BSI values at harvest were non-significant and ranged from $74 \%$ to $83 \%$. The highest value was recorded on the $\mathrm{S}_{30}+\mathrm{N}_{0}$ plot. 
Table 9. Total S uptake (TSU) and onion bulb S index (BSI) in relation to interaction between $\mathrm{N}$ and S rate and day after emergence (DAE).

\begin{tabular}{|c|c|c|c|c|c|c|c|c|c|}
\hline \multirow{2}{*}{$\begin{array}{r}\text { S Rate, } \\
\text { kg ha }^{-1}\end{array}$} & \multirow{2}{*}{$\begin{array}{l}\text { N Rate, } \\
\text { kg ha }^{-1}\end{array}$} & \multicolumn{8}{|c|}{ DAE } \\
\hline & & 20 & 30 & 40 & 50 & 60 & 70 & 80 & 90 \\
\hline \multicolumn{10}{|c|}{ TSU, $\mathrm{g} \mathrm{m}^{-2}$} \\
\hline \multirow[t]{3}{*}{0} & 0 & 0.01 & 0.06 & 0.12 & 0.13 & $0.27^{\mathrm{c}}$ & $0.38^{c}$ & $0.36^{c}$ & $0.54^{b}$ \\
\hline & 60 & 0.01 & 0.06 & 0.15 & 0.19 & $0.33^{b, c}$ & $0.49^{a, b, c}$ & $0.53^{b, c}$ & $0.76^{a, b}$ \\
\hline & 120 & 0.01 & 0.05 & 0.15 & 0.29 & $0.29^{c}$ & $0.46^{b, c}$ & $0.49^{b, c}$ & $0.83^{a, b}$ \\
\hline \multirow[t]{3}{*}{30} & 0 & 0.01 & 0.09 & 0.14 & 0.21 & $0.30^{b, c}$ & $0.41^{c}$ & $0.54^{\mathrm{b}}$ & $0.67^{a, b}$ \\
\hline & 60 & 0.01 & 0.08 & 0.21 & 0.26 & $0.34^{b, c}$ & $0.59^{a, b}$ & $0.66^{a, b}$ & $0.69^{a, b}$ \\
\hline & 120 & 0.01 & 0.06 & 0.16 & 0.35 & $0.40^{a, b}$ & $0.56^{\mathrm{a}, \mathrm{b}}$ & $0.83^{\mathrm{a}}$ & $0.61^{b}$ \\
\hline \multirow[t]{3}{*}{60} & 0 & 0.01 & 0.06 & 0.14 & 0.32 & $0.40^{\mathrm{a}, \mathrm{b}}$ & $0.62^{\mathrm{a}}$ & $0.84^{\mathrm{a}}$ & $0.90^{\mathrm{a}, \mathrm{b}}$ \\
\hline & 60 & 0.01 & 0.06 & 0.19 & 0.26 & $0.47^{\mathrm{a}}$ & $0.64^{\mathrm{a}}$ & $0.78^{\mathrm{a}}$ & $1.03^{\mathrm{a}}$ \\
\hline & 120 & 0.01 & 0.07 & 0.18 & 0.41 & $0.36^{b, c}$ & $0.45^{b, c}$ & $0.71^{a, b}$ & $1.07^{\mathrm{a}}$ \\
\hline$F$-test & & n.s. & n.s. & n.s. & n.s. & $4.2^{* *}$ & $6.6^{* * *}$ & $5.1^{* * *}$ & $3.0^{*}$ \\
\hline \multicolumn{10}{|c|}{ BSI, \% } \\
\hline \multirow[t]{3}{*}{0} & 0 & - & - & - & 0.41 & $0.54^{a, b}$ & 0.44 & 0.66 & 0.74 \\
\hline & 60 & - & - & - & 0.33 & $0.49^{b, c}$ & 0.45 & 0.69 & 0.78 \\
\hline & 120 & - & - & - & 0.37 & $0.39^{c, d}$ & 0.53 & 0.76 & 0.78 \\
\hline \multirow[t]{3}{*}{30} & 0 & - & - & - & 0.37 & $0.56^{\mathrm{a}}$ & 0.45 & 0.73 & 0.83 \\
\hline & 60 & - & - & - & 0.40 & $0.34^{\mathrm{d}}$ & 0.49 & 0.74 & 0.79 \\
\hline & 120 & - & - & - & 0.33 & $0.52^{a, b}$ & 0.47 & 0.85 & 0.79 \\
\hline \multirow[t]{3}{*}{60} & 0 & - & - & - & 0.36 & $\begin{array}{l}0.44 \\
b, c, d\end{array}$ & 0.47 & 0.72 & 0.81 \\
\hline & 60 & - & - & - & 0.41 & $0.53^{a, b}$ & 0.44 & 0.74 & 0.77 \\
\hline & 120 & - & - & - & 0.37 & $0.51^{b, c}$ & 0.51 & 0.79 & 0.76 \\
\hline$F$-test & & - & - & - & n.s. & $14.7^{* * *}$ & n.s. & n.s. & n.s. \\
\hline
\end{tabular}

$*, * * * * * F$-test significant at $p<0.05,0.01,0.001$, respectively. $n . s .$, not significant. Letters indicate statistically significant differences between treatments at $p<0.05$ (HSD test).

The in-season TSU trend was completely different from TDW and TNU, fitting the quadratic regression model best (Table 10). TSU parameters, analogous to the dynamic parameters described for onion DW and TNU, were variable year to year. The absolute $\mathrm{S}$ uptake $\left(\mathrm{SC}_{\mathrm{m}}\right)$ and predicted $\mathrm{S}$ accumulation $\left(\mathrm{TSU}_{\mathrm{t} 2}\right)$ reached their highest values in 2009. In that year, the two parameters were 4 -fold and 1.7-fold higher compared to 2010 and 2011, respectively. The opposite trend was obtained for the relative $S$ uptake rate $\left(S R_{m}\right)$.

Table 10. Dynamics of total S of Allium cepa depending on year and fertilization treatment: quadratic model parameters.

\begin{tabular}{|c|c|c|c|c|c|c|}
\hline \multirow{2}{*}{ Factors } & & \multicolumn{3}{|c|}{ Absolute Growth Rate } & \multicolumn{2}{|c|}{ Relative Growth Rate } \\
\hline & & $\mathrm{SC}_{\mathrm{m}} \mathrm{mg} \mathrm{m}^{-2} \mathrm{~d}^{-1}$ & $\mathrm{TSU}_{\mathrm{T} 2} \mathrm{mg} \mathrm{m}^{-2}$ & $\mathbf{R}^{2}(p)$ & $\mathrm{SR}_{\mathrm{m}} \mathrm{mg} \mathrm{mg^{-1 } \mathrm { d } ^ { - 1 }}$ & $\mathbf{R}^{2}(p)$ \\
\hline \multicolumn{7}{|l|}{ Year } \\
\hline 2009 & & 29.57 & 1230.3 & $0.70 * * *$ & 0.106 & $0.93^{* * *}$ \\
\hline 2010 & & 7.38 & 335.7 & $0.71^{* * *}$ & 0.130 & $0.92^{* * *}$ \\
\hline 2011 & & 17.86 & 831.9 & $0.84^{* * *}$ & 0.153 & $0.95^{* * *}$ \\
\hline S Rate kg S ha ${ }^{-1}$ & $\mathrm{~N}$ Rate $\mathrm{kg} \mathrm{N} \mathrm{ha}{ }^{-1}$ & & & & & \\
\hline \multirow[t]{3}{*}{0} & 0 & 10.48 & 522.9 & $0.67^{* * *}$ & 0.126 & $0.83^{* * *}$ \\
\hline & 60 & 16.75 & 744.6 & $0.59 * * *$ & 0.130 & $0.77^{* * *}$ \\
\hline & 120 & 19.35 & 795.4 & $0.64^{* * *}$ & 0.135 & $0.80^{* * *}$ \\
\hline \multirow[t]{3}{*}{30} & 0 & 14.29 & 668.3 & $0.69^{* * *}$ & 0.110 & $0.80^{* * *}$ \\
\hline & 60 & 21.80 & 815.8 & $0.76^{* * *}$ & 0.115 & $0.83^{* * *}$ \\
\hline & 120 & 17.63 & 911.2 & $0.66^{* * *}$ & 0.138 & $0.85^{* * *}$ \\
\hline \multirow[t]{3}{*}{60} & 0 & 19.62 & 955.5 & $0.58^{* * *}$ & 0.132 & $0.87^{* * *}$ \\
\hline & 60 & 22.64 & 1023.0 & $0.51^{* * *}$ & 0.132 & $0.81^{* * *}$ \\
\hline & 120 & 26.01 & 1022.0 & $0.44 * *$ & 0.134 & $0.81^{* * *}$ \\
\hline
\end{tabular}

$*$ **, *** at $p<0.05,0.01,0.001$, respectively. $\mathrm{SC}_{\mathrm{m}}$, maximum absolute $\mathrm{S}$ accumulation rate computed at time $\mathrm{T}_{2}=90$ days after emergence; $\mathrm{SR}_{\mathrm{m}}$, maximum of relative $\mathrm{S}$ uptake rate computed at $\mathrm{T}=20$ days after emergence; $\mathrm{TSU} \mathrm{U}_{\mathrm{T} 2}$, predicted total $S$ accumulation at 90 days after emergence. 
The impact of $\mathrm{N}$ doses on $\mathrm{SC}_{\mathrm{m}}$ was independent of $\mathrm{S}$ doses, but there some trends were observed. On the $S_{30}$ plot, the highest $S_{m}$ was recorded on the $S_{30}+N_{60}$ plot. The $N$ rate of $120 \mathrm{~kg} \mathrm{ha}^{-1}$ resulted in a slightly lower $\mathrm{SC}_{\mathrm{m}}$ increase with respect to $\mathrm{N}_{0}$. On the other $\mathrm{S}$ plots, the highest $\mathrm{SC}_{\mathrm{m}}$ values were recorded on the plot fertilized with an $\mathrm{N}$ rate of $120 \mathrm{~kg} \mathrm{ha}^{-1}$. This parameter displayed the highest impact as well as a positive impact on TDW $\left(r=0.88^{* * *}\right)$. In addition, it was significantly correlated with $\mathrm{NC}_{\mathrm{m}}\left(\mathrm{r}=0.82^{* * *}\right)$.

$\mathrm{TSU}_{\mathrm{T} 2}$ increased in accordance with increasing $\mathrm{S}$ rates. The effect of $\mathrm{N}$ rates was, in general, only related to the respective $\mathrm{N}$ controls. This parameter of the TSU model showed the same level of correlation with yield $\left(\mathrm{r}=0.87^{* * *}\right)$ as $\mathrm{SC}_{\mathrm{m}}$. The maximum relative $\mathrm{S}$ uptake parameter showed an opposite trend to the previously described parameters of the model. The impact of fertilization was weakly differentiated, ranging from 0.110 to $0.138 \mathrm{mg} \mathrm{mg}^{-1} \mathrm{~d}^{-1}$ for $\mathrm{S}_{30}+\mathrm{N}_{0}$ and $\mathrm{S}_{30}+\mathrm{N}_{120}$, respectively. This parameter did not show a significant correlation with any of the studied parameters of the developed model.

\section{Discussion}

\subsection{Yield of Bulbs}

The key objective of the present study was to explain the impact of progressively increasing rates of $\mathrm{N}$ and $\mathrm{S}$ fertilizers on the dynamics of onion biomass during the growing season and eventually on its yield. The key factor affecting onion yield was, in fact, the weather. The effect of $\mathrm{N}$ was only revealed in 2009, a year characterized by little precipitation. In spite of this, the onion yield was the highest of all the studied years, and it was obtained with fertilizer treatment of $\mathrm{N}$ at a rate $60 \mathrm{~kg} \mathrm{ha}^{-1}$. In the other two years, the effect of $\mathrm{N}$ was negligible, in spite of more favorable precipitation and temperature during the growing season [31]. The yield of onion increased progressively with the $S$ rate, but independent of the level of applied $\mathrm{N}$ (Figure 2b). It is necessary to stress that onion yield responded significantly to $S$ rates, even on the $\mathrm{N}$ control plots. The positive impact of $S$ on onion yield is frequently reported in different world regions. A gradual increase of onion yield with $S$ applied at rates increasing progressively to $50 \mathrm{~kg} \mathrm{ha}^{-1}$ was reported in [24]. As reported in [25], application of $30 \mathrm{~kg} \mathrm{ha}^{-1}$ of $\mathrm{S}$ as $\mathrm{S}^{0}$ resulted in a yield increase of $13 \%$, and $60 \mathrm{~kg} \mathrm{ha}^{-1}$ resulted in an increase of $44 \%$. This phenomenon can be explained by the fact that $\mathrm{S}^{0}$ added to the soil undergoes oxidation, subsequently leading to the release of available $S$ to the plant and accelerated mineralization of soil organic $\mathrm{N}$, resulting in increased ammonium $\mathrm{N}$ content [32].

\subsection{Dynamics of Onion Biomass During the Season and Its Partitioning Between Organs}

The in-season course of total onion dry weight (TDW) increment was best described by the expolinear function. The early pattern of onion growth as related to leaves, however, did not persist up to harvest. This conclusion is supported by the fact that onion yield significantly but negatively responded to the $R_{m}$ growth parameter, which describes the maximum relative biomass growth during the exponential phase, which is related to leaf expansion (Table 4). The relationship obtained indicates that too rapid early onion growth resulted in lower bulb yield.

The second important piece of information refers to the mode of bulb growth. The linear mode of growth indirectly indicates an immature status of harvested onion. In spite of this, all parameters of the TDW model were positively correlated with the final onion biomass, but their impact on onion yield was insignificant. In addition, these parameters were subsequently negatively correlated with $R_{m}$, thus corroborating the above hypothesis on the dominant role of the linear phase in onion yield performance (Table S1). The yield indicative $R_{m}$ function was corroborated by the stepwise regression analysis:

$$
\mathrm{Y}=3000.3-10,840 \mathrm{R}_{\mathrm{m}} \text { for } \mathrm{n}=9, \mathrm{R}^{2}=0.74 \text { and } p<0.05
$$

The development of a bulb by an onion plant is a function of two factors, thermal time and photoperiod, as documented in [33]. Therefore, the onset of bulb development (bulbing) seems to be 
independent of agronomic factors. This hypothesis, in spite of the extreme sensitivity of in-season onion biomass development to weather, was confirmed for 2010 and 2011, but not 2009, and especially by the $\mathrm{S}_{60}+\mathrm{N}_{120}$ treatment.

The progressive increase in BDWI during the bulbing phase, with the exception of plants grown on the AC plot, corroborates the hypothesis on the immature status of onion at harvest. The BDWI variability, as recorded at the onset of bulbing (DAE 50), clearly explains the response of the onion to $\mathrm{N}$ supply. As a rule, plants grown in absolute control conditions, i.e., without $\mathrm{N}$ and $\mathrm{S}$ application, displayed the highest index value (49\%), but those with a high $\mathrm{N}$ supply had the lowest $(40 \%)$. These results are in line with the observation that a shortage of $\mathrm{N}$ accelerates, but an excess delays, onion bulbing [13]. However, too little $\mathrm{N}$ supply during the bulbing phase resulted in a much lower BDWI at harvest, as observed on the absolute control (70\%), consequently resulting in the lowest yield.

An onion maturity index, i.e., a net negative BDWI value, considered between DAE 90 and 80, can be used to explain the effect of $\mathrm{N}$ supply on the maturity status of harvested onion. The only plants grown on the AC plot reached maturity (-1). The highest unripe status of onion was recorded in 2009, when the computed $T_{b}$, i.e., the day when the plant changes its mode of growth from exponential to linear, was revealed on the 86th DAE, or four days before harvest. An even more extreme result was recorded on the $S_{60}+S_{120}$ plot (+9) (Table 3). The computed Tb for this treatment was noted 25 days beyond the harvest. These results stress that onion biomass performance throughout the entire growing season followed the exponential model. This conclusion is supported by the extremely high biomass of onion at harvest (Table 4). The harvested onion yield was also the highest in 2009 . These facts indicate that the exponential regression model is the most productive for describing the in-season pattern of onion growth. This was revealed under conditions of a good supply of both sulfur and nitrogen over the entire growing season. Therefore, the expolinear model of in-season onion biomass growth can be treated as an indicator of bulb growth disturbance.

\subsection{Dynamics of Total Nitrogen Uptake by Onion and Its Partitioning Between Organs During the Season}

In general, the in-season trend of $\mathrm{N}$ uptake by onion and its subsequent partitioning among the plant organs, as in the case of biomass, was best described by the expolinear model. Two critical points during onion growth should be taken into consideration. The first one appears at the onset of bulbing, which was detected for most of the studied treatments before the 40th DAE. At this stage, plants fertilized only with $\mathrm{S}$ at rates of 30 and $60 \mathrm{~kg} \mathrm{ha}^{-1}$ took up $39 \%$ and $54 \%$ more $\mathrm{N}$ with respect to the SN control, respectively. Simultaneously applied S and N resulted in a higher N uptake of $50 \%$ for plants fertilized with $\mathrm{S}$, independent of the applied rate. The interactional effect of $\mathrm{S}$ and $\mathrm{N}$ continued up to harvest. Therefore, TNU on the 40th DAE can be used to predict $\mathrm{N}$ uptake at harvest:

$$
\mathrm{TNU}_{90}=2.4 \mathrm{TNU}_{40}+2.7 \text { for } \mathrm{n}=9, \mathrm{R}^{2}=0.89 \text { and } p<0.001
$$

At harvest, onion yield showed a significant but lower response to $\mathrm{TNU}\left(\mathrm{TNU}_{\mathrm{H}}\right)$. This relationship can be described by the quadratic regression model:

$$
\mathrm{Y}=-4.78 \mathrm{TNU}_{\mathrm{H}}^{2}+88.9 \mathrm{TNU}_{\mathrm{H}}-148.8 \text { for } \mathrm{n}=9, \mathrm{R}^{2}=0.79 \text { and } p<0.05
$$

The regression model obtained clearly suggests that an onion yield of $264.5 \mathrm{~g} \mathrm{~m}^{-2}$ was possible, provided $\mathrm{TNU}_{\mathrm{H}}$ reached $9.3 \mathrm{~g} \mathrm{~m}^{-2}$. This value was exceeded in 2009 on the 80th and 90th DAE, leading to a decreased yield for the plot fertilized with $\mathrm{N}$ at a rate of $120 \mathrm{~kg} \mathrm{ha}^{-1}$. This relationship clearly shows that under a favorable supply of $\mathrm{S}$, from both soil resources and fertilizer, the required $\mathrm{N}$ rate can be significantly reduced. This was the case in 2009. Under these conditions, the ratio of $\mathrm{N}$ dose to $\mathrm{S}$ dose of 1:1 was sufficiently high to result in a high onion yield. Under unfavorable growth conditions, which characterized the other two years, a dose ratio 1:2 of the two fertilizers was required for a relatively high yield, but it was much lower than in the growing conditions of 2009. The $\mathrm{N}$ partitioning index (BNI) was 21\% higher in 2011 than in 2009, despite a significantly lower yield. These results 
show that $\mathrm{N}$ taken up by onion in that year was not efficiently transformed into yield. In 2011, the BNI increased progressively up to harvest, but yield was low compared to 2009.

The applied stepwise regression analysis clearly indicated that onion yield depended on two indices of the TNU model, $\mathrm{NC}_{\mathrm{m}}$ and $\mathrm{NR}_{\mathrm{L}}$ :

$$
\mathrm{Y}=3458+6284 \mathrm{NC}_{\mathrm{m}}-100,025 \mathrm{NR}_{\mathrm{L}} \text { for } \mathrm{n}=9, \mathrm{R}^{2}=0.74 \text { and } p<0.05
$$

This equation clearly stresses that the higher the maximum $\mathrm{N}$ accumulation rate during the linear phase of growth, i.e., in bulbs, the higher the expected yield. The impact of $\mathrm{NC}_{\mathrm{m}}$ was only slightly modified by the relative rate of bulb growth.

\subsection{Dynamics of Sulfur Uptake by Onion and Its Partitioning Between Organs During the Season}

The general trend of in-season $S$ uptake by onion can be described by the quadratic regression model. The in-season course of $S$ accumulation in leaves indicates this organ is a temporary source of the nutrient for the enlarging bulb. The observed trends fully corroborate the hypothesis in [34], stating that sink strength is the driver of source activity. In the studied case, this conclusion refers to the requirement of $S$ by the growing bulb. In 2011, the dominance of leaves as the $S$ storage organ was broken down by the enlarged bulb much later in comparison to both previous years. The main reason was the excessive supply of $\mathrm{N}$, which delayed the mode of onion growth change from exponential to linear. The accelerated enlargement of bulb biomass, occurring just after a significant drop in the $S$ content in leaves, stresses the growth driving function.

The importance of $S$ as a nutrient driving yield was fully corroborated by the stepwise regression analysis. Among all parameters of the developed model, the highest impact on onion yield was exerted by the maximum absolute $\mathrm{S}$ accumulation rate computed on the 90 th $\mathrm{DAE}\left(\mathrm{SC}_{\mathrm{m}}\right)$ :

$$
\mathrm{Y}=1630.6+37.8 \mathrm{SC}_{\mathrm{m}} \text { for } \mathrm{n}=9, \mathrm{R}^{2}=0.78 \text { and } p<0.01
$$

This model clearly explains that the higher the $\mathrm{S}$ uptake rate during the final stages of bulb growth, the higher the onion yield that can be expected. The value of this parameter was significantly affected by the interaction of $\mathrm{S}$ and $\mathrm{N}$ supply. This dependence was fully corroborated by a significant relationship between $\mathrm{SC}_{\mathrm{m}}$ and $\mathrm{NC}_{\mathrm{m}}\left(\mathrm{r}=0.82^{* *}\right)$. This relationship was not linear, and fit the quadratic regression model best:

$$
\mathrm{SC}_{\mathrm{m}}=-710.4 \mathrm{NC}_{\mathrm{m}}{ }^{2}+359.5 \mathrm{NC}_{\mathrm{m}}-18.5 \text { for } \mathrm{n}=9, \mathrm{R}^{2}=0.89 \text {, and } p<0.001
$$

The obtained model indicates that the maximum $\mathrm{SC}_{\mathrm{m}}$ of $27 \mathrm{mg} \mathrm{m}^{-2} \mathrm{~d}^{-1}$ can be obtained provided $\mathrm{NC}_{\mathrm{m}}$ is $0.25 \mathrm{~g} \mathrm{~m}^{-2} \mathrm{~d}^{-1}$, i.e., at an $\mathrm{NC}_{\mathrm{m}} / \mathrm{SC}_{\mathrm{m}}$ ratio of 9.25:1. A value larger than this results in $\mathrm{SC}_{\mathrm{m}}$, consequently resulting in decreased onion yield. Under limited $S$ supply to the onion, i.e., a lack of $S$ fertilization, $\mathrm{SC}_{\mathrm{m}}$ fully depended on the $\mathrm{N}$ rate and on $\mathrm{S}$ supply from soil resources. In $2009, \mathrm{~S}$ soil resources were sufficiently high to meet the onion requirement for $\mathrm{S}$, but under a much lower $\mathrm{N}$ rate of $60 \mathrm{~kg} \mathrm{ha}^{-1}$ (Table 2). Application of $\mathrm{S}$ fertilizer increased $\mathrm{TSU}_{\mathrm{p}}$ in accordance with the increasing $\mathrm{N}$ rate, but $\mathrm{SC}_{\mathrm{m}}$ reached the highest value on plots fertilized with $\mathrm{N}$ at the rate of $60 \mathrm{~kg} \mathrm{ha}^{-1}$. This relationship clearly shows that a too high $\mathrm{N}$ rate can substantially reduce the rate of $\mathrm{S}$ accumulation by onion, subsequently leading to decreased yield. Therefore, a delicate relationship between the two nutrients, as reported by numerous authors, should be considered in fertilizing onion with sulfur [16,23].

\section{Conclusions}

Onion is a crop highly sensitive to the supply of S. Applied elementary S significantly increased the supply of $\mathrm{N}$ to onion, inducing its supply from soil resources, as recorded on plots without $\mathrm{N}$ fertilizer. The supply of this nutrient during the phase of bulb enlargement is a decisive factor in bulb yield. It can therefore be considered as a yield driver. The response of onion to fertilization with $S$ 
significantly depends on its supply from soil resources and the level of applied N. Under favorable growth conditions, as indicated by a sufficiently high content of available soil $\mathrm{S}$, the rate of $\mathrm{N}$ can be significantly reduced. Too high an $\mathrm{N}$ rate reduces the maximum $\mathrm{S}$ uptake rate during onion bulbing, subsequently leading to a yield drop. Under favorable growth conditions, including the course of weather and the optimum S-to-N supply ratio, the onion biomass pattern is best described by the exponential regression model. Plants following this growth model have the highest yield potential. The expolinear model is an indicator of onion growth disturbance, revealed under unfavorable growth conditions, leading to yield depression.

Supplementary Materials: The following are available online at http://www.mdpi.com/2073-4395/10/8/1146/s1, Table S1: Correlation matrix: relationships between yield of onion bulbs and parameters describing dynamics of plant growth and $\mathrm{N}$ and $\mathrm{S}$ accumulation.

Author Contributions: Conceptualization, K.P.-C.; methodology, P.B.; validation, W.G.; formal analysis, T.S.; investigation, K.P.-C.; data curation, P.B.; writing-original draft preparation, K.P.-C.; writing-review and editing, W.G.; visualization, P.B. and T.S.; supervision, W.G.; project administration, W.G. All authors have read and agreed to the published version of the manuscript.

Funding: This publication is being co-financed through the framework of the Ministry of Science and Higher Education program "Regional Initiative Excellence" in 2019-2022, project no. 005/RID/2018/19.

Conflicts of Interest: The authors declare no conflict of interest.

\section{References}

1. Ben-Noun, L. Health Effects of Onions; B.N Publication House: Beer-Sheva, Israel, 2018.

2. Ren, F.; Reilly, K.; Gaffney, M.; Kerry, J.; Hossaina, M.; Raia, D. Evaluation of polyphenolic content and antioxidant activity in two onion varieties grown under organic and conventional production systems. J. Sci. Food Agric. 2016, 97, 2982-2990. [CrossRef] [PubMed]

3. Yoo, K.S.; Pike, L.M. Determination of background pyruvic acid concentration in onion, Allium species, and other vegetables. Sci. Hortic. 2001, 89, 249-256. [CrossRef]

4. FAO Statistical Pocketbook 2015. World Food and Agriculture; Food and Agriculture Organization of the United Nations: Rome, Italy, 2015; Available online: http://www.fao.org/3/a-i4691e.pdf (accessed on 14 May 2020).

5. Kraciński, P. Przemiany na rynku cebuli w latach 1995-2012. Sci. J. Wars. Univ. Life Sci.-SGGW Econ. Organ. Agri-Food Sect. 2014, 107, 143-154. [CrossRef]

6. Hanci, F. Comprehensive Overview of Onion Production: Worldwide and Turkey IOSR. J. Agric. Vet. Sci. (IOSR-JAVS) 2018, 11, 17-27.

7. Pire, R.; Ramirez, H.; Riera, J.; Gomez de, T.N. Removal of N, P, K and Ca by an onion crop (Allium cepa L.) in silty-clay soil, in a semiarid region of Venezuela. Acta Hortic. 2001, 555, 103-109. [CrossRef]

8. Bender, D.A. Onions. In Nutrient Deficiencies \& Toxicities in Crop Plants; Bennett, W.F., Ed.; APS Press: St. Paul, MA, USA, 1993; pp. 131-135.

9. Khokhar, K.M. Mineral nutrient management for onion bulb crops-A review. J. Hortic. Sci. Biotech. 2019, 94, 703-717. [CrossRef]

10. Lee, J.; Hwang, S.; Lee, S.; Ha, I.; Hwang, H.; Lee, S.; Kim, J. Comparison Study on Soil Physical and Chemical Properties, Plant Growth, Yield, and Nutrient Uptakes in Bulb Onion from Organic and Conventional Systems. Hortic. Sci. 2014, 49, 1563-1567. [CrossRef]

11. Gebretsadik, K.; Dechassa, N. Response of Onion (Allium cepa L.) to nitrogen fertilizer rates and spacing under rain fed condition at Tahtay Koraro, Ethiopia. Sci. Rep. 2018, 8, 9495. [CrossRef]

12. Nawaz, M.Q.; Ahmed, K.; Hussain, S.S.; Rizwan, M.; Safraz, M.; Wainse, G.M.; Jamil, M. Response of onion to different nitrogen levels and method of transplanting in moderately salt affected soil. Acta Agric. Slov. 2017, 109, 303-313.

13. Drost, D.T.; Koenig, R.; Tindal, T. Nitrogen Use Efficiency and Onion Yield Increased with a Polymer-coated Nitrogen Source. Hortic. Sci. 2002, 37, 338-342. [CrossRef]

14. Rizk, A.M.; Fatma, A.; Shaheen, E.H.; Abd, E.; Omaima, M.S. Effect of different nitrogen plus phosphorus and sulphur fertilizer levels on growth, yield and quality of onion (AIlium Cepa L.). JASR 2012, 8, 3353-3361.

15. McCallum, J.; Porter, N.; Searle, B.; Shaw, M.; Bettjeman, B.; McManus, M. Sulfur and nitrogen fertility affects flavour of field-grown onions. Plant Soil 2005, 269, 151-158. [CrossRef] 
16. De Souza, L.F.G.; Filho, A.B.C.; de Túlio, F.A.; Nowaki, R.H.D. Effect of sulphur dose on the productivity and quality of onions. Aust. J. Crop Sci. 2015, 9, 728-733.

17. Liu, S.; He, H.; Feng, G.; Chen, Q. Effect of nitrogen and sulfur interaction on growth and pungency of different pseudostem types of Chinese spring onion (Allium fistulosum L.). Sci. Hortic. 2009, 121, 12-18. [CrossRef]

18. Randle, W.M.; Bussard, M.L. Pungency and sugars of short-day onions as affected by sulfur nutrition. J. Am. Soc. Hortic. Sci. 1993, 118, 766-770. [CrossRef]

19. Mishu, H.M.; Ahmed, F.; Rafii, M.Y.; Faruq, G.; Latif, M.A. Effect of sulphur on growth, yield and yield attributes in onion (Allium cepa L.). Aust. J. Crop Sci. 2013, 7, 1416-1422.

20. Tripathy, P.; Sahoo, B.B.; Priyadarshini, A.; Das, S.K.; Dash, D.K. Effect of sources and levels of sulphur on growth, yield and bulb quality in onion (Allium cepa L.). Int. J. Bio-Resour. Stress Manag. 2013, 4, 641-644.

21. Hamilton, B.K.; Yoo, K.S.; Pike, L.M. Changes in pungency of onions by soil type, sulphur nutrition and bulb maturity. Sci. Hortic. 1998, 74, 249-256. [CrossRef]

22. Nasreen, S.; Haque, M.M.; Hossain, M.A.; Farid, A.T.M. Nutrient uptake and yield of onion as influenced by nitrogen and sulphur fertilization. J. Agric. Res. 2007, 32, 413-420. [CrossRef]

23. Pradhan, R.; Pattnaik, A.K.; Tripathy, P.; Mallikarjunarao, K.; Sahoo, B.B.; Lenka, J. Influence of sulphur fertilization on nutrient uptake of onion (Allium cepa L.). J. Crop Weed 2015, 11, 134-138.

24. Meher, R.; Mandal, J.; Saha, D.; Mohanta, S. Effect of sulphur application in onion (Allium cepa L.). J. Crop Weed 2016, 12, 86-90.

25. Przygocka-Cyna, K.; Biber, M.; Pluta, M.; Grzebisz, W. Mineral density of onion bulbs as affected by fertilizers based on elemental sulfur. J. Elem. 2016, 21, 485-499. [CrossRef]

26. Kumari, A.; Ram, B.; Kumar, U.; Prasad, S.S. Growth, yield and bulb quality as influenced by sources and levels of sulphur in onion (Allium cepa L.) under calcareous soil of North Bihar. Asian J. Soil Sci. 2018, 13, 126-130. [CrossRef]

27. 27. Rehm, G.; Schmitt, M. Sulfur for Minnesota Soils. University of Minnesota Extension Publication FO-00794-GO. Available online: https://extension.umn.edu/micro-and-secondary-macronutrients/sulfurminnesota-soils (accessed on 16 May 2020).

28. Bardsley, C.E.; Lancaster, J.D. Determination of reserve sulfur and soluble sulfates in soils. Soil Sci. Soc. Am. J. 1980, 24, 265-268. [CrossRef]

29. Goudriaan, J.; Monteith, L. A Mathematical Function for Crop Growth Based on Light Interception and Leaf Area Expansion. Ann. Bot. 1990, 66, 695-701. [CrossRef]

30. Hunt, R. Plant Growth Curves. In The Functional Approach to Plant Growth Analysis; Edward Arnold Ltd.: London, UK, 1982.

31. Kalbarczyk, R. Effect of agrometeorological conditions on onion field in central Poland. Folia Univ. Agric. Stetin. Agric. Aliment. Piscaria Zootech. 2008, 266, 43-58.

32. Skwierawska, M.; Zawartka, L.; Zawadzki, B. The effect of different ratios and forms of sulphur applied on changes of soil agrochemical properties. Plant Soil Environ. 2008, 54, 171-177. [CrossRef]

33. Lancaster, J.E.; Triggs, C.M.; de Ruitter, J.M.; Gandar, P.W. Bulbing in onions: Photoperiod and temperature requirements and prediction of bulb size and maturity. Ann. Bot. 1996, 78, 423-430. [CrossRef]

34. Körner, C. Paradigm shift in plant growth control. Curr. Opin. Plant Biol. 2015, 25, 107-114. [CrossRef]

(C) 2020 by the authors. Licensee MDPI, Basel, Switzerland. This article is an open access article distributed under the terms and conditions of the Creative Commons Attribution (CC BY) license (http://creativecommons.org/licenses/by/4.0/). 